\title{
The relationship between public listing, context, multi-nationality and internal CSR
}

\author{
Marc Goergen $^{\text {a,h,*, }}$, Salim Chahine ${ }^{\mathrm{b}}$, Geoffrey Wood ${ }^{\mathrm{c}}$, Chris Brewster ${ }^{\text {d,ef,g }}$ \\ a Cardiff Business School, Cardiff University, Aberconway Building, Colum Drive, CF10 3EU, UK \\ ${ }^{b}$ Olayan School of Business, American University of Beirut Bliss Street, PO Box 11-0236, Beirut, Lebanon \\ ${ }^{c}$ Essex Business School, University of Essex, Wivenhoe Park, Colchester CO4 3SQ UK \\ ${ }^{\mathrm{d}}$ Henley Business School, University of Reading, Whiteknights, Reading RG6 6UD, UK \\ e Vaasa University, Finland \\ ${ }^{\mathrm{f}}$ Radboud University, Nijmegen, Netherlands \\ ${ }^{g}$ ISCTE-Instituto Universitário de Lisboa, Portugal \\ ${ }^{\mathrm{h}}$ European Corporate Governance Institute, Brussels, Belgium
}

\section{A R T I C L E I N F O}

\section{Article history:}

Received 16 October 2017

Accepted 20 November 2017

Available online 22 November 2017

\section{JEL classification:}

G1

G3

\section{Keywords:}

Corporate governance

Legal institutions

Corporate social responsibility (CSR)

MNES

Country of domicile pressures

\begin{abstract}
A B S T R A C T
Are MNEs more socially responsible, and where is this more likely to occur? Are firms less responsible in emerging or transitional economies, and what impact does the dominant national corporate governance regime have? We explore the association between public listing and the existence of a CSR code within specific institutional settings and assess whether MNEs are any different to their local counterparts, based on an internationally comparative survey. We find that listed firms as well as firms from civil law countries are more likely to have CSR statements. MNEs are also more likely to have CSR statements, independent of their country of origin. While we find consistent evidence of a correlation between the existence of a CSR statement and investment in staff training, the correlation between the former and employee-friendly HRM is weaker.
\end{abstract}

(C) 2017 The Authors. Published by Elsevier B.V. This is an open access article under the CC BY license (http://creativecommons.org/licenses/by/4.0/).

\section{Introduction}

This is a study of the relationship between institutional contexts, dominant corporate governance regimes, and the relative propensity of firms to behave in a socially responsible manner, comparing firms that are multi-national enterprises (MNEs) with those that are not, and taking account of the effects of public listing. There is a growing body of comparative corporate governance literature that explores the effects of national institutional arrangements on how firms behave (Hancke et al., 2007; La Porta et al., 2008). This includes studies that extend such analyses to explore the relative propensity of firms to engage in socially responsible behavior (Cai et al., 2016; Matten and Moon, 2008). However, most strands of this literature have tended to neglect the case of firms that cross national boundaries, though there have been notable exceptions (Attig et al., 2016). Recently, Morgan (2012) argues that such firms are only partially embedded in a single institutional domain, but as they enter markets to reap the advantages they confer, they have quite strong incentives to seek to fit in with dominant modes of practice. Within the international business and human resource management (HRM) literature, there has been an extensive debate on country of origin and

\footnotetext{
* Corresponding author.

E-mail addresses: goergenm@cf.ac.uk (M. Goergen), sc09@aub.edu.lb (S. Chahine), gtwood@essex.ac.uk (G. Wood), Chris.Brewster@henley.reading.ac.uk (C. Brewster).
} 
country of domicile effects on the managerial practices MNEs might adopt (Brookes et al., 2017; Brewster et al., 2008), but this has tended to neglect issues of corporate social responsibility (CSR). This study, therefore, seeks to supplement the existing literature through providing new insights on a key dimension of corporate behavior in the light of dominant corporate governance regimes and organizational characteristics.

Carter, Kale and Grimm (2000: 219) define CSR as: “... the managerial consideration of non-market forces or social aspects of corporate activity [that] ... includes consideration of issues such as employee welfare, community programs, charitable donations, and environmental protection"; in other words, it incorporates both internal and external dimensions. Hence, CSR is about embarking on actions to further some or other social good, which may be internal or external to the firm (Campbell et al., 2012; Mellahi et al., 2010). The latter is about the extent to which the firm engages in socially responsible behavior towards the wider community, and the former towards internal stakeholders, above all, employees. Although both dimensions of CSR are important, it could be argued that it is much harder for firms to bluff about internal responsibility: It may be much harder to measure the outcomes of broad community orientated initiatives than immediate treatment of employees (Campbell et al., 2012; Mellahi et al., 2010). Hence, this study seeks to supplement earlier comparative work that explores variations in external CSR (Campbell et al., 2012; Cai et al., 2016) through looking at not only public commitments to CSR, but also at the internal dimension.

Agency approaches suggest that agency issues are most likely to arise in listed firms, given the separation of ownership from operational control (Jensen, 1986). A commitment to CSR may then be seen as the inappropriate pursuit of prestige by managers, diverting firm resources away from what rightfully belongs to shareholders, a means of repairing any collateral reputational damage in contexts where owner rights are weak, or, simply, a virtuous act. It has been suggested that CSR expenditures constitute a waste of resources and are not in the best interest of shareholders (Borghesi et al., 2014; Becchetti et al., 2015). Whatever, the rationale, such choices are likely to be molded by context and ownership form (Wood et al., 2014; Matten and Moon, 2008). It could be argued that it is easier to espouse CSR with 'other people's money', in listed firms in those settings where shareholder rights are relatively weak. CSR might also be higher in firms that are trying to build reputation and acquire market share in foreign markets (Bermiss et al., 2013; Cottrill, 1990). However, it could also be the case that, developing the argument beyond Minor and Morgan (2011), where stakeholder rights are weaker, reputational scandals are more likely and, hence, a commitment to CSR more likely. This paper explores whether listed firms and MNEs are more or less likely to espouse CSR, and whether, in turn, this is affected by institutional frameworks, and the associated dominant corporate governance regime.

Our paper takes the following form. First, we review the literature on the links between institutional setting and CSR. In Section 3, we then explore the rationales for CSR while considering issues of listing, whether a firm is an MNE or not, and context, and develop our hypotheses from theories in the existing literature. In Section 4, we then explain how we test these hypotheses with an internationally comparative survey. We then present and discuss our findings in Section 5 . This is followed by robustness tests before drawing conclusions for theory and for practice in Section 7.

\section{Setting and CSR: existing evidence}

Cai et al. (2016) explore variations in external CSR (which they refer to as corporate social performance - CSP, as a short-hand for its absorption into regular practice). They evaluate the effects of institutions, culture and national development, as well as a range of firm specific characteristics, finding that the former exert a much greater effect than the latter. In terms of the former, they find that relative national development exerts quite strong effects - developed countries are associated with higher CSR. However, they note that this does not provide a full explanation: Other important factors are civil liberties, property rights, political rights and culture. They explain the overriding effects of context, as context determines the relative costs and benefits of investing in CSR.

Ioannou and Serafeim (2012) explore the relations between institutions and propensity to engage in externally socially responsible behavior, using the Business Systems Theory (BST) taxonomy of comparative capitalisms developed by Whitley (1999). The broad distinctions between liberal markets and coordinated ones remain the same as in Hall and Soskice (2001), but BST also highlights the differences between European and Asian coordinated markets and identifies Northern Italy as a category in its own right. Moreover, BST further unpacks national level systemic configurations, highlighting the distinct roles of political, cultural, labor, educational and financial systems (Whitley, 1999). Ioannou and Serafeim (2012) find that all of the above, other than the financial system, affect CSR. They explain the latter by arguing that investors are unlikely to prioritize CSR (Ioannou and Serafeim, 2012). However, later work by Cheng et al. (2014) suggests that CSR is associated with lower capital constraints: They ascribe this to socially responsible firms being more transparent and having closer ties to stakeholders, which may make them more attractive to investors. This study seeks to build on earlier work on contextual dynamics through exploring how responsibly firms behave internally.

Within the corporate finance literature, the predominant focus on the consequences of institutional arrangements is on the extent to which this imposes a corporate governance regime that is property owner rights centered or not. The legal origin literature suggests that, within common law countries owner rights are strongest, and hence, are most able to bring managers into line with their agendas (La Porta et al., 2008). This would suggest that, within common law countries (refer to Panel A of Table 1 for the list of 30 common law and civil law countries covered by this study), differences in firm level practices between listed and non-listed firms will be less pronounced than in civil law countries, where owner rights are weaker (La Porta et al., 2008). Hence, we explore the differences between common law and civil law countries. However, we also include the La Porta et al. (2008) investor protection index as a control variable to account for differences within a given legal family. We find that the latter has explanatory power, albeit weaker explanatory power than legal family. 
Table 1

Sample distribution.

Our matched sample is obtained by selecting pairs of firms from the full sample. In each pair, one firm is located in a common law country and the other in a civil law country. We match firms in each pair by listing status (listed or non-listed), profitability (measured on a Likert scale ranging from 1 (lowest) to 5 (highest profitability)), industry and closest size ( $\pm 10 \%$ as measured by the number of employees).

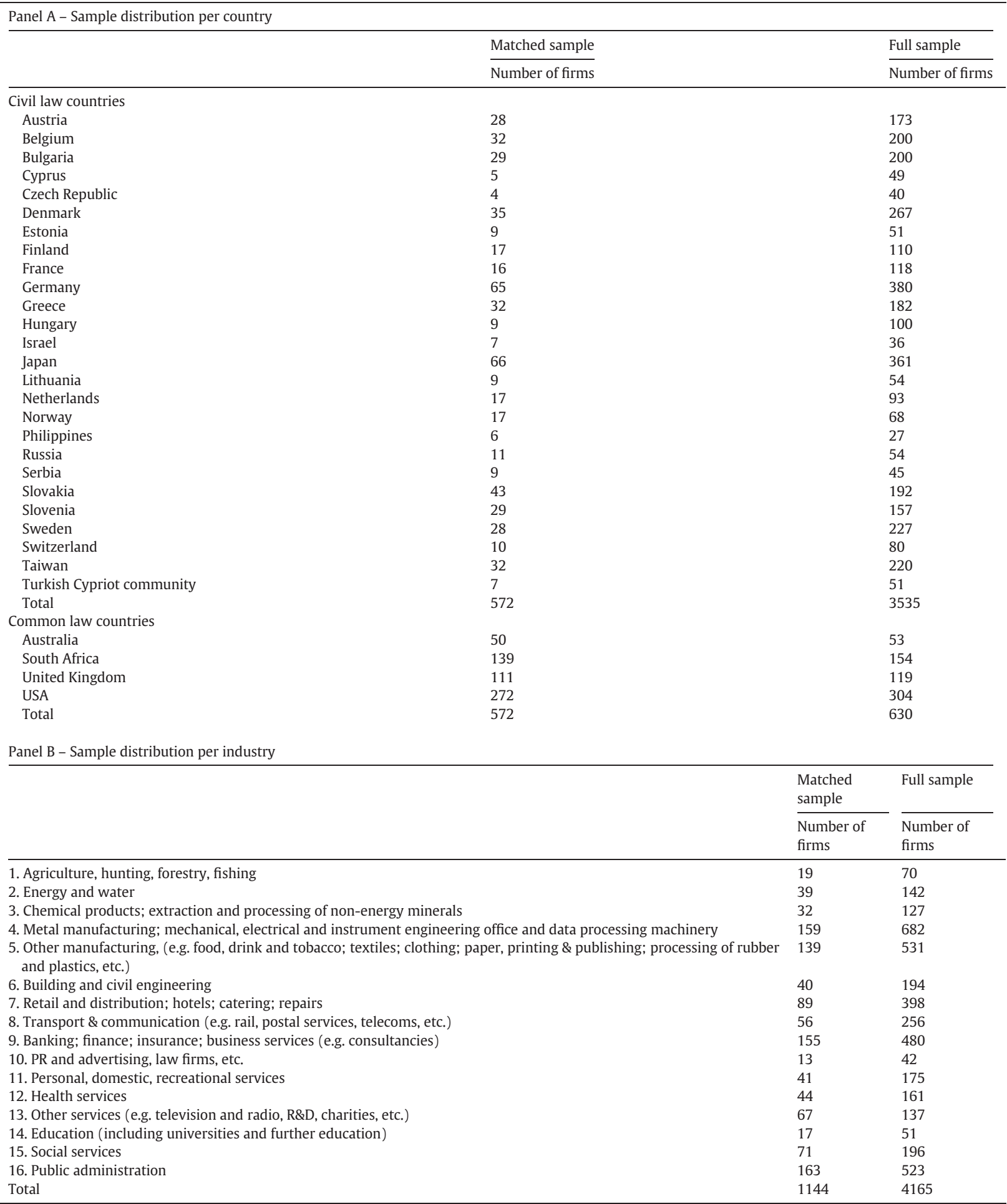


Our focus is on explaining the existence of a CSR statement. However, a CSR statement may just be 'cheap talk' and the firm may decouple its practices from what it writes in its CSR statement. Hence, we also investigate whether the existence of a CSR statement correlates with internal CSR practice - more employee-friendly HRM as well as greater investment in training. While we find consistent and strong evidence that a CSR statement correlates with more investment in training, we find less consistent evidence of such a correlation with employment change practices.

A limitation of the legal origins literature is its narrow focus on the law and macro-economic outcomes, with the firm being depicted as a mere transmission belt. In other words, there is a tendency to neglect variations in intra-firm dynamics and practices (Wood et al., 2014). This body of literature is also largely silent on the case of MNEs. On the one hand, it could be argued that it is country of origin that really matters, as this is where owners will seek to exercise their rights. On the other hand, applied developments and extensions of this perspective suggest that, within countries of domicile, strong property owner rights are also necessary to prevent subsidiaries from being diverted into unprofitable directions (see Cooney et al., 2011).

This paper further seeks to redress a shortfall in the literature through an examination of the position of MNEs. As noted above, MNEs are only partially rooted in any institutional domain, and, hence, may be more able to depart from accepted norms in countries of domicile, even if they may reap real benefits from fitting in with dominant modes of practice (Morgan, 2012).

In a subsequent step, we remove transitional and emerging market economies, in order to account for any possible effects of great disparities in economic development which, above all, characterize the civil law camp. A frequent criticism of La Porta et al. is their tendency to lump economies together, regardless of stages of national development, which potentially confuses the nature of causality (Du, 2010). It is difficult to imagine that the substitution of formal institutional-legal mechanisms could possibly cause a large range of emerging markets to experience a rapid transformation in their fortunes (Hancke et al., 2007). We find that our results are upheld - and even added to and strengthened - when removing transitional and emerging market economies from our sample. In contrast, when we focus on the sub-sample of transitional and emerging market economies our results become much weaker or disappear altogether.

\section{Listing, MNEs, institutional context and CSR}

The core focus of the paper is on internal CSR; in other words, not just on formal commitments to CSR, but also on how they are matched by policies and practices towards a core stakeholder grouping, employees. A key measure of the firm's commitment to internal CSR is to evaluate the kind of employment practices that it adopts (Mellahi et al., 2010). At the simplest level, CSR is about acting with restraint. Although it could be argued that such behavior is good for the bottom line, and hence, devoid of moral worth, this would discount the extent to which extending such commitment to employees would leave them personally much better off, and hence, result in a better overall good, regardless of rationale (Mellahi et al., 2010).

If the focus is on shareholder value, the interests of a range of other internal stakeholders may be jeopardized (Beer et al., 2015; Harrison and Wicks, 2013). Bučiūnienè and Kazlauskaitè (2012) found that organizations that had more systematic and developed approaches to human resource management (HRM) also had more developed CSR policies, reflecting the extent to which social responsibility may be correlated with how employees are treated. The commitment of a firm to its people may be evidenced by a relative reluctance to downsize, and, where external circumstances necessitate it, the use wherever possible of 'softer' and more voluntary mechanisms (Goergen et al., 2013). It may also be reflected by a relative propensity to invest in the workforce (Whitley, 1999). Together, these can be seen as measures of relative interdependence, and the extent to which the firm will bind itself into long-term commitment to its workforce (Whitley, 1999). Hence, although higher levels of interdependence are likely to be encountered in settings where stakeholder rights are stronger, it could be argued that more socially responsible firms in all contexts will be committed to promoting higher levels of interdependence, regardless of setting.

\subsection{Listing and CSR}

Neo-liberal critiques see CSR as an attempt by managers to enhance their own prestige, and a misdirection of shareholder value (Agle et al., 2008; Friedman, 1970). In listed firms, managers have some independence to direct organizational resources away from shareholders to activities that enhance their standing (Ioannou and Serafeim, 2014) and are therefore more likely to formally commit to CSR. Hence, investors may shun firms for wasting resources on CSR. Alternatively, it could be argued that commitment to CSR may be viewed favorably by many investors, given this may make potential customers more positively inclined to the firm and/or because this signals a commitment to placing the business on a more sustainable footing (Cheah et al., 2011). There are a growing number of investors who implicitly or explicitly combine a longer-term focus with a commitment to CSR (Crane and Matten, 2016). Managers may seek to attract such investors through formally committing the firm to CSR: What is bad in the short term may be best in the long term (Laverty, 1996). Similarly, managers may seek to discourage short-termist investors that wish to impose practices that may be detrimental to the long-term sustainability of the firm, and/or otherwise challenge their autonomy (Laverty, 1996). If such investors are hostile to CSR, then a formal commitment to it may discourage them. In other words, the investment ecosystem is maybe changing, and those firms that are likely to respond most immediately to these changes will be listed.

Further, investors in the financial markets may exercise greater pressures on listed companies, pushing them to make formal commitments in written form. Written codes represent a more formal obligation and "are voluntary statements that commit organizations, industries, or professions to specific beliefs, values, and actions, and/or that set out appropriate ethical behavior" 
(Crane and Matten, 2007: 175). There is an expectation that, in order to attract and retain investors, listed firms will make more written information as to their present condition, policies and strategies, available than their non-listed counterparts.

Hypothesis 1. Listed firms are more likely to have a CSR statement.

\subsection{MNES and CSR}

MNEs are less rooted in a single national context than indigenous firms and may be subject to a wide range of both country of origin and country of domicile pressures across the locales in which they operate (Marano and Kostova, 2016; Brewster et al., 2008: Zander et al., 2016). However, MNEs will still be influenced by host country pressures (Bondy and Starkey, 2014) and, as they are more likely to have a higher profile than domestic firms (Crane et al., 2008), they will be more susceptible to negative publicity. The negative stereotypes encapsulated in their liability of foreignness may be partially combatted by a CSR statement, thus enhancing their competitiveness vis-à-vis domestic firms (Campbell et al., 2012).

Hence, MNEs take up voluntary CSR codes in order to defend their reputation and market position. Weaver et al. (1999) explain that companies subject to media pressure are more likely to invest in policies that will help restore lost legitimacy and avoid future negative media attention. So, we expect MNEs to be more likely to have CSR codes. Not only may they have more room to pioneer new ways of doing things that challenge local norms, but they may also face strong pressures to be seen as legitimate in the host country if they want to benefit from a particular local production or, for that matter, market regime (Boiral, 2003; Palazzo and Scherer, 2006; Morgan, 2012; Van Cranenburgh et al., 2013; Bausch and Krist, 2007).

Hypothesis 2. MNEs are more likely to have CSR statements than their domestic counterparts.

\subsection{Legitimacy, CSR, and institutional context}

From a financial perspective, and based on the so-called 'universal owner' hypothesis, CSR may be driven by shareholders, such as pension funds, recognizing the virtues of long-term sustainability in their holdings and mindful of corporate reputations (Hawley and Williams, 2000; Deakin and Hobbs, 2007; Mellahi et al., 2010). There is evidence that the public espousal of CSR indeed originated in liberal markets (Kinderman, 2012; Kaplan, 2015), partly in response to 'corporate excess', leading to pressures from governments and campaigning stakeholders (Palazzo and Scherer, 2006; Van Cranenburgh et al., 2013). A positive CSR image may also enhance market position (Becker-Olsen et al., 2006; Park et al., 2014; Shea, 2010). However, neoliberal approaches to the firm, more dominant in common law countries, traditionally suggested that "the social responsibility of business is to increase its profits" (Friedman, 1970: 173), with CSR representing an agency failing. In turn, such approaches have directly impacted on both the governance of firms and the type of agendas managers are incentivized to follow.

In civil law countries, shareholders are seen as just one among a number of stakeholders (others being managers, employees and their trade unions, consumers, communities and governments). Under the law, owner rights are mediated by those of other stakeholders, in turn making for a systemically embedded impact on what the firm does. Publicly-listed companies may be particularly likely to be receptive to other stakeholder interests because, in such contexts, agency problems are more likely to be pronounced (Pagano et al., 1998) and/or because they are more open to scrutiny (Van Cranenburgh et al., 2013; Sen and Cowley, 2013). However, it could also be argued that, in such contexts, while firms may be expected to be more socially responsible, this is likely to be implicit, and acted out through low key day-to-day decisions rather than one-off public gestures: Tighter regulation makes for fewer reputational scandals, reducing the need for public gestures (Matten and Moon, 2008). Within civil law countries investors tend to be patient (Dore, 2000). They are more likely to value the potential long-term benefits for an organization accruing from being socially responsible, even if it entails upfront costs, and hence, are more likely to encourage organizations to tie themselves into formal commitments to CSR (Fogarty, 1995; Sacconi, 1999).

Becchetti et al. (2013) suggest that it is firms in common law countries that tend to do better in terms of community involvement, which might suggest reputation is taken seriously (c.f. Liang and Renneboog, 2017; Gjølberg, 2009). Impelled by legitimacy concerns, but pulled by short-term pressures to maximize profits, firms operating in such jurisdictions would be less likely to have a CSR statement that formally commits them for a sustained period of time (Matten and Moon, 2008). So:

Hypothesis 3. Firms in common law countries are less likely to have a CSR statement.

\subsection{CSR and employer-employee interdependence}

Talk is easy, but deeds are more difficult. As Mellahi et al. (2010) note, firms faced with reputational challenges may seek to engage in window dressing, in proclaiming a commitment to responsibility, while carrying on with business as usual. One way of testing a firm's commitment to CSR is to evaluate how it treats a core internal stakeholder, evidenced by the kind of employment practices that it adopts. If the focus is on shareholder value, the interests of a range of other stakeholders may be jeopardized (Beer et al., 2015; Bučiūnienė and Kazlauskaitè, 2012; Harrison and Wicks, 2013). Hence, although higher levels of employer-employee interdependence are likely to be encountered in settings where stakeholder rights are stronger, it could be argued that 
more socially responsible firms in all contexts will be committed to promoting higher levels of interdependence, regardless of setting:

Hypothesis 4. There will be a correlation between the existence of a CSR statement and higher levels of employer-employee interdependence.

\section{Data and methodology}

To test our hypotheses, we followed a multi-stage data selection process. Our firm-level data initially consists of 6155 firms from 31 countries (later dropping down to 30 countries; see below) included in the 2009/10 wave of the Cranet survey on employment practices (for full details see Brewster et al., 2004 and Parry et al., 2013). These surveys are conducted every four to five years and cover all major sectors within the target economies and all organizations with over 100 employees. The Cranet survey records HRM policies and practices, and provides detailed insights into internal practices, supplementing studies based on external CSR. Ninety percent of respondents are at HRM director level, and the others are CEOs or the most senior HRM specialist. Given the sensitivity of the questions asked, responses are anonymous. Stratified sampling is conducted on the basis of industrial distribution according to the EU NACE categorization of industries, except in smaller countries where full population surveys are conducted: The survey seeks to ensure representativeness in the light of prevailing employment structures. The sampling method enabled both listed and non-listed firms to be captured. The questionnaire was administered in the main language(s) of the country under review. Response rates ranged from $10 \%$ to $40 \%$, but in most countries, response rates were around the $20 \%$ mark; this represents quite a respectable rate of return for specialist surveys of this nature (Mellahi and Harris, 2016).

We use a matched sample as well as an un-matched sample in the study. The first one adjusts for the possible endogeneity of the presence of a CSR statement (see e.g. Hillman and Keim, 2001; Waddock and Graves, 1997). The second sample uses all the available observations from Cranet for a total of 4165 firms and is used as a robustness check. To obtain our matched sample, we selected pairs of firms. For each pair, one firm must be located in a common law country and the other in a civil law country. We match firms in each pair by listing status (listed or non-listed), profitability measured on a Likert scale ranging from 1 (poor or at the low end of the industry) to 5 (superior) (i.e. firms having similar flexibility in terms of implementing CSR activities), industry (i.e. similar business practices) and closest size, i.e. $\pm 10 \%$, as measured by the number of employees (i.e. similar internal pressures from their employees). Out of the original total population of 6155 firms, we first excluded 1868 firms with missing data on the number of employees, profitability, and industry, and another 122 firms with missing data on the control variables. This resulted in a sample of 4165 firms from 30 countries (we lost Iceland with only 138 observations in the original sample), including 2574 listed firms and 1591 non-listed firms. Using our matching criteria, our final sample includes 1144 firms (i.e. 572 pairs of firms located in common law and civil law countries), which represent pairs of firms with the same listing status, within the same class of profitability, same industry, and within a close range of size. Panel A of Table 1 reports the distribution across the 30 countries of the 572 pairs of companies as well as the un-matched sample from civil law and common law countries. Panel B presents the sample distribution across industries for our matched sample as well as the un-matched sample.

To test the validity of the first three hypotheses about the likelihood of a firm having a CSR code, we estimate the following probit equation at the firm level. The equation specifies the hypothesized sign for each variable's coefficient. We elaborate on the coefficients' signs below.

$$
\begin{aligned}
\text { CSR dummy }= & \alpha+\beta_{1} \text { Listed dummy }-\beta_{2} \text { Common Law dummy }+\beta_{3} \text { MNE dummy } \\
& + \text { Firm-level variables }+ \text { Country-level variables }+ \text { Industry dummies }+\varepsilon
\end{aligned}
$$

where CSR dummy is a dummy variable, which is equal to one if the firm has a CSR code, and zero otherwise.

To test the validity of the fourth hypothesis about whether there is a correlation between the existence of a CSR statement and higher levels of employer-employee interdependence, we estimate the following ordinary least squares (OLS) regression, which is based on Eq. (1) augmented by CSR dummy:

$$
\begin{aligned}
\text { Employer-employee Interdependence }= & \gamma+\delta_{1} \text { CSR dummy }+\delta_{2} \text { Listed dummy }-\delta_{3} \text { Common Law dummy } \\
& +\delta_{4} \text { MNE dummy }+ \text { Firm-level variables }+ \text { Country-level variables }+ \text { Industry dummies } \\
& +\eta
\end{aligned}
$$

where Employer-employee Interdependence is in the form of one of the following two measures. First, we use Adjusted Employment Change, which is the ratio of Employment Change to Firm Size. Employment Change is a score indicating the increase/decrease of employees in the firm. It is equal to zero if the company had an increase in its number of employees during the previous three years, 1 if the number of employees remained stable during the last three years, 2 if the company had a recruitment freeze, 3 if the company practiced redeployment, 4 if the company had voluntary redundancies, 5 if the company had early retirements, 6 if the company did not renew fixed-term/temporary contracts, 7 if the company used outsourcing or outplacement, and 8 if the company had compulsory redundancies during the last three years. Most firms will use more than one employment practice and in such cases we focus on the most stringent employment practice. Hence, the Employment Change index methodology takes 
account of the extent to which managers may 'soften' the effects of workforce adjustments (Goergen et al., 2013). Firm Size is the logarithm of the total number of employees.

Second, we use Training Index, which measures the level of training provided by the firm. Training Index ranges from zero to five, and it is equal to the sum of the four dummy variables High Number of Days per Year Training (as a percentage of staff turnover) per category of employee (management, professional, clerical, and manual) plus High Percentage Annual Payroll Costs Spent on Training dummy. High Number of Days per Year Training (as a percentage of staff turnover) is a dummy variable, which is set to one if the firm offers a number of training days (adjusted by staff turnover), which exceeds the sample median. High Percentage Annual Payroll Costs Spent on Training dummy is the equivalent dummy variable for an above median spent on training. Again, Training Index explores variations in investment in people within different organizations. It takes account of the time spent on training employees, to distinguish between those organizations that spend a large proportion of their resources on basic induction training necessitated by high staff turnover rates and those that are genuinely committed to investing in their people (Goergen et al., 2012).

We include various dummy variables in our regressions based on Eq. (1) to test the validity of the first three hypotheses. To test the validity of Hypothesis 1, we use Listed dummy, which is equal to one if the firm is listed, and zero otherwise. If Hypothesis 1 is valid, the coefficient on this dummy variable will be positive and significant. We include MNE dummy, which is equal to one if the firm has a presence in more than one country, and zero otherwise, to verify our Hypothesis 2 . If Hypothesis 2 is valid, the coefficient on this dummy variable will be positive and significant. The validity of Hypothesis 3 is tested using Common Law dummy, which is set to one if the firm is from a common law country, and zero otherwise. If the coefficient on this dummy variable is negative and significant, then Hypothesis 3 is upheld.

The validity of Hypothesis 4 is tested by including the CSR dummy on the right-hand side of Eq. (1) above, i.e. it is tested using Eq. (2). If the coefficient on the CSR dummy, which is defined as above, is positive and significant, Hypothesis 4 is validated.

To test our predictions on the differential effects of the legal origin on both our publicly listed firms and MNEs we augment Eqs. (1) and (2) by a number of interactions. First, we use the interactions between Listed dummy and each of the two legal family dummies, i.e. Common Law dummy and Civil Law dummy. The latter dummy variable is set to one if the firm originates from a civil law country, and is zero otherwise. Apart from the interactive effect between legal origin and listing status (regressions (4a), (5a), and (6a) in Table 5), we also include the interactive effect between legal origin and MNE status (regressions (4b), (5b), and (6b) in Table 5), as well as the interactive effect between legal origin and both listing status and MNE status (regressions (4c), (5c), and $(6 c)$ in Table 5).

As controls, we include firm size, measured by the logarithm of the total number of employees, as large companies have greater visibility and are therefore more likely to have a CSR statement (Deegan et al., 2002; Gray et al., 1995; Guthrie and Parker, 1989; Patten, 1991; Woodward et al., 1996). ${ }^{1}$ We also control for profitability (defined as above) as the CSR literature suggests that more profitable firms have more resources to spend on CSR (see e.g. Waddock and Graves, 1997). We also add the level of innovation by the firm (as a proxy for R\&D expenditures) and we expect a positive association between CSR dummy and the level of innovation. Indeed, R\&D is likely to lead to product and process innovation, which also causes better CSR-related processes and products (McWilliams and Siegel, 2000). Rating of Innovation is measured on a Likert scale ranging from 1 (poor or at low end of industry) to 5 (superior). Our regressions include Family dummy, which is equal to one if the firm is owned and/or controlled by primarily one family, and zero otherwise. As family firms have relationships of a more personal nature with their employees and customers, they are also more concerned about their image and reputation than non-family firms. As such we expect family firms to be more likely to have a CSR statement and to have greater employer-employee dependence (Dyer and Whetten, 2006; Goergen and Renneboog, 2010).

Furthermore, Avi-Yonah (2005) describes the transformations undergone by the corporate form over time and argues that CSR becomes legitimate and normatively accepted as corporations grow - even when it does not contribute to long-run shareholder wealth. As such, we predict a positive association between CSR and M\&A activities. We include M\&A dummy as a control variable. This is equal to one if the firm was involved in M\&As during the three-year period prior to the year of the Cranet survey, and zero otherwise. Given that companies from some industries may be more visible and may therefore be more exposed to public scrutiny, we also use industry dummies.

In addition to the above firm-level variables, we control for a number of country-level variables. The likelihood of having a CSR statement and greater employer-employee dependence might negatively depend on investor rights and economic wealth. We control for investor rights and economic development using the Djankov et al. (2008) anti-self-dealing index and GNI per capita, respectively. Djankov et al. (2008) anti-self-dealing index, Investor Rights, measures the level of protection enjoyed by minority shareholders. We use the natural logarithm of gross national income (GNI) per capita, Ln GNI, (World Bank, 2017) rather than raw GNI to control for skewness. Further country-level variables include a number of variables used by extant literature (see e.g. Cai et al., 2016; Ioannou and Serafeim, 2012). These are Absence of Corruption (Corruption Perception Index from Transparency International, 2010); Lack of Civil Liberties E Political Rights (Freedom House annual survey of civil liberties and political rights, from Freedom in the World 2010 report); Harmony, Egalitarianism, Intellectual Autonomy, and Affective Autonomy (Schwartz, 1999); Individualism and Power Distance (Hofstede, 1980); and Political (measures whether the country's laws

\footnotetext{
1 See also Wickert et al. (2016) who develop a theoretical model of how firm size affects CSR engagement. They argue that for large firms it is relatively less costly to 'talk CSR' (i.e. to communicate about CSR) but costlier to 'walk CSR' (i.e. to engage in actual CSR) whereas for small firms the converse is true. The reason for this is that for large firms communicating about CSR will be relative cheap whereas engaging in CSR will be relatively costly given the greater organizational complexity, such as the greater number of domestic and foreign subsidiaries, which makes it costlier to enforce and oversee CSR across the organization.
} 
Table 2

Descriptive statistics.

This table reports descriptive statistics for the matched sample of 1144 firms as well as the sub-samples of firms from civil and common law countries. The latter two represent pairs of listed and non-listed companies within the same class of profitability, and within a close range of size. Common Law firms are firms that are headquartered in a common law country, and Civil Law firms are those headquartered in civil law countries. CSR dummy is equal to one if the firm has a CSR code, and zero otherwise. Listed dummy equals one if the firm is listed, and zero otherwise. Employment Change is a composite score from 1 to 5 indicating the increase/decrease of employees in the firm. Training is a composite score ranging from zero (lowest) to five (highest) and indicating the level of training provided by the firm. All other variables are defined in the Appendix. ${ }^{* * *},{ }^{* *}$, and ${ }^{*}$ denote significance of the difference in means at the $1 \%, 5 \%$, and $10 \%$ level (for the two-tailed test), respectively. The $t$-test is used for continuous variables, and the binomial test (z-test) is used for proportions, i.e. dummy variables.

\begin{tabular}{|c|c|c|c|c|c|c|c|}
\hline & \multirow{2}{*}{\multicolumn{2}{|c|}{$\begin{array}{l}\text { Full matched sample } \\
(\mathrm{N}=1144)\end{array}$}} & \multirow{2}{*}{\multicolumn{2}{|c|}{$\begin{array}{l}\text { Civil law } \\
(\mathrm{N}=572)\end{array}$}} & \multirow{2}{*}{\multicolumn{2}{|c|}{$\begin{array}{l}\text { Common law } \\
(\mathrm{N}=572) \\
\end{array}$}} & \multirow[t]{3}{*}{$\mathrm{p}$-values of $t$-test diff/z-test diff } \\
\hline & & & & & & & \\
\hline & Mean & S.d. & Mean & S.d. & Mean & S.d. & \\
\hline CSR dummy & 0.504 & 0.500 & 0.586 & 0.493 & 0.423 & 0.494 & $0.000^{* * *}$ \\
\hline Employment Change $^{\mathrm{a}}$ & 2.359 & 3.336 & 2.069 & 3.164 & 2.648 & 3.478 & $0.005^{* * *}$ \\
\hline \multicolumn{8}{|l|}{ Adjusted Employment } \\
\hline Index & 0.014 & 0.044 & 0.018 & 0.050 & 0.010 & 0.037 & $0.003^{* * *}$ \\
\hline Training Index ${ }^{\mathrm{a}}$ & 2.808 & 1.573 & 2.946 & 1.506 & 2.670 & 1.630 & $0.092^{*}$ \\
\hline Listed dummy & 0.542 & 0.498 & 0.542 & 0.499 & 0.542 & 0.499 & 1.000 \\
\hline MNE dummy & 0.444 & 0.497 & 0.444 & 0.497 & 0.444 & 0.497 & 1.000 \\
\hline Size (no. of employees) & 2493.190 & 8231.691 & 2512.381 & 8415.763 & 2473.998 & 8050.735 & 0.937 \\
\hline Rating of profitability & 3.572 & 0.888 & 3.572 & 0.890 & 3.572 & 0.888 & 1.000 \\
\hline Rating of Innovation & 3.520 & 0.927 & 3.437 & 0.904 & 3.603 & 0.942 & $0.002^{* * *}$ \\
\hline Family dummy & 0.233 & 0.423 & 0.257 & 0.437 & 0.210 & 0.408 & $0.059^{*}$ \\
\hline M\&A dummy & 0.379 & 0.485 & 0.360 & 0.480 & 0.399 & 0.490 & 0.180 \\
\hline Investor Rights & 0.576 & 0.217 & 0.396 & 0.132 & 0.755 & 0.110 & $0.000^{* * * *}$ \\
\hline GNI per Capita '08 (\$) & $34,117.6$ & $13,758.5$ & $32,182.2$ & $12,140.4$ & $36,053.0$ & $14,967.5$ & $0.000^{* * *}$ \\
\hline GNI Growth Rate & 1.408 & 2.895 & 1.928 & 3.540 & 0.889 & 1.927 & $0.000^{* * *}$ \\
\hline Absence of Corruption & 6.840 & 1.569 & 6.763 & 1.859 & 6.917 & 1.207 & $0.097^{*}$ \\
\hline Harmony & 3.986 & 0.360 & 4.281 & 0.189 & 3.691 & 0.223 & $0.000^{* * *}$ \\
\hline Affective Autonomy & 3.836 & 0.346 & 3.823 & 0.416 & 3.850 & 0.257 & 0.181 \\
\hline Intellectual Autonomy & 4.423 & 0.343 & 4.640 & 0.274 & 4.205 & 0.257 & $0.000^{* * *}$ \\
\hline Egalitarianism & 4.708 & 0.237 & 4.720 & 0.307 & 4.697 & 0.135 & 0.113 \\
\hline Civil Liberties & 1.302 & 0.580 & 1.360 & 0.695 & 1.243 & 0.429 & $0.001^{* * *}$ \\
\hline Power Distance & 46.348 & 18.088 & 51.829 & 23.865 & 40.867 & 5.023 & $0.000^{* * *}$ \\
\hline Individualism & 68.827 & 21.536 & 53.448 & 18.313 & 84.206 & 10.917 & $0.000^{* * *}$ \\
\hline Political & 4.928 & 0.672 & 4.937 & 0.902 & 4.918 & 0.301 & 0.642 \\
\hline Labor Market & 4.950 & 0.613 & 4.679 & 0.425 & 5.221 & 0.651 & $0.000^{* * * *}$ \\
\hline Macroeconomic & 5.193 & 0.384 & 5.289 & 0.493 & 5.097 & 0.185 & $0.000^{* * *}$ \\
\hline Infrastructure & 5.312 & 0.985 & 5.164 & 1.148 & 5.461 & 0.760 & $0.000^{* * *}$ \\
\hline
\end{tabular}

a The data for Employment Change is available for 1046 observations ( 523 observations in each sub-sample), and for 370 observations in the case of the Training Index (185 observations in each sub-sample).

encourage competition), Infrastructure (the quality of basic infrastructure in the country), Macroeconomic (measuring macro-economic performance), ${ }^{2}$ and Labor Market (the availability of skilled labor) (all four from Ioannou and Serafeim, 2012). All of these variables are defined in detail in the Appendix.

We acknowledge that there is a risk in survey based studies of common method variance (CMV) bias, the most serious being if two different sets of perceptions based variables from the same dataset are used as a source of both independent and dependent variables, which may reflect the effects of how the data was collected, rather than any genuine relationship (Mitchell, 1985; Podsakoff and Organ, 1986). CMV is most commonly associated with perceptions data (León et al., 2013), whereas the questions in the Cranet survey ask managers to report on practices, with close ended response categories, and in no instance did we compare two sets of perceptions data. As the survey is anonymized, it is not possible to match up individual responses and company data. We recognize that a comparison of internal CSR with performance would represent a fertile ground for future research. Finally, in making use of the La Porta et al. legal origin taxonomy, we compare firm level practices with independently derived societal categorizations, imparting a dimension of comparison with a secondary data source.

\section{Empirical results}

Table 2 presents descriptive statistics for the matched sample of 572 firm pairs, i.e. a total of 1144 firms, as well as the subsamples of the 572 firms from common law countries and the 572 firms from civil law countries. Just over half of the sample firms (50.4\%) have a CSR statement. A larger percentage of firms from the civil law countries have a CSR statement (58.6\%) compared to firms from common law countries (42.3\%), and the difference is significant at the $1 \%$ level. Moreover, the average for Employment Change is 2.359, with a value of two indicating an employment freeze and a value of three indicating redeployment. This is significantly higher at the $1 \%$ level for firms from common law countries (2.648) than for those from civil law countries

2 This is equivalent to Balance of Trade in Ioannou and Serafeim (2012). 
(2.069). The average adjusted employment change divided by the number of employees is 0.014 on average, and it is significantly higher (at the $10 \%$ level) for firms from common law countries (0.017) than for those from civil law countries (0.012). In other words, firms from civil law countries are more likely to change levels of employment through 'softer' mechanisms. ${ }^{3}$

The average for Training Index is equal to 2.808 out of five, thus suggesting that firms provide an average level of training to their employees. The value for Training Index is significantly lower in common law countries than civil law countries (2.670 and 2.946 , respectively) at the $10 \%$ level. ${ }^{4}$

The sample includes $54.2 \%$ of firms that are listed and $44.4 \%$ of firms that are MNEs. The average firm has 2493 employees and a profitability score of 3.572 out of 5 and, by construction, there is no difference in the percentages of listed firms, in the likelihood of being an MNE, as well as in the means for the number of employees and the profitability between the two sub-samples of matched firms. Moreover, the average innovation score is equal to 3.520 out of 5, and firms in common law countries have a significantly higher score than those in civil law countries (at the $1 \%$ level).

Slightly less than one quarter of the firms are family firms (23.3\%). Some $37.9 \%$ of firms were involved in merger and acquisition deals (M\&A) during the three years prior to the survey, and they are located in countries with average investor rights of 0.576 and average GNI per capita of $\$ 22,716$. As expected, the firms from the civil law countries are more likely to be family firms (the difference is significant at the $10 \%$ level). The civil law countries also have lower investor rights and a lower GNI per capita, but a higher GNI growth rate, than the common law countries (at the $1 \%$ level), albeit many of the countries included in the matched sample are from emerging and transitional economies. We subsequently revisit our analysis with these countries removed. Further, our country-level variables indicate that common law countries have on average higher scores for Individualism, Labor, and Infrastructure, but lower scores for Harmony, Intellectual Autonomy, Civil Liberties, Power Distance, and Macroeconomic than civil law countries (at the 1\% level). Table 3 reports the pairwise correlation coefficients. Listed firms and MNEs are more likely to have a CSR statement, whereas firms from common law countries are less likely to have such a statement. The table also indicates more training in firms with a CSR statement, and less training in firms with less employee-friendly employment change. Hence, CSR statements seem to be linked to more socially responsible practices within the firm.

Table 4 tests the validity of our four hypotheses via regression analysis. It reports the results from estimating the binomial probit regression using CSR dummy as the dependent variable (regressions (1a) and (1b)). Regression (1b) is similar to regression (1a), but includes the country-level variables. Regressions (1a) and (1b) show that both listed firms and MNEs are more likely to have a CSR statement (at the 1\% level and the 10\% level or better, respectively). This provides support for both Hypotheses 1 and 2. Further, firms from common law countries are less likely to have a CSR statement as reflected by the significantly negative coefficient on Common Law dummy in regressions (1a) and (1b) (at the 5\% level or better). This suggests that Hypothesis 3 is also valid.

Regressions (2a) and (2b) are the OLS regressions on the adjusted employment change. Similar to regressions (1a) and (1b), regression (2b) is identical to regression (2a) augmented with the country-level variables. Regressions (2a) and (2b) indicate that adjusted employment change is lower in listed firms, but higher in firms from common law countries (at the 5\% level and the 5\% level or better, respectively). However, there is no significant association with the MNE dummy. This suggests that both Hypotheses 1 and 3 are valid.

Regressions (3a) and (3b) are the ordered probit regressions on the training index. Again, regression (3b) includes the country-level variables in addition to the variables included in regression (3a). Regressions (3a) and (3b) show greater training in both listed firms and MNEs (at the 5\% level), and less training in firms from common law countries (at the $10 \%$ level or better). This provides empirical support for our first three hypotheses. Moreover, regressions (3a) and (3b) indicate greater training in firms with a CSR statement (at the $1 \%$ level), confirming Hypothesis 4.

As to the firm-level control variables, Table 4 suggests that larger firms are more likely to have a CSR statement and are more likely to make 'softer' employment changes (at the $1 \%$ level). This is in line with our expectations and the extant literature. We also find a positive correlation between firms generating more innovation on the one side and firms having a CSR statement, engaging in softer HRM practices and firms offering more training to their employees on the other side (at the $10 \%$ level or better).

In terms of the country-level control variables, a CSR statement is more likely for firms from countries with stronger investor rights, as well as firms from countries with no corruption, greater harmony, intellectual autonomy, egalitarianism, less individualism and political openness to competition (at the $10 \%$ level or better). However, the existence of a CSR statement is less likely for firms from countries with a higher GNI, higher GNI growth, and greater availability of skilled labor (at the 5\% level or better). Moreover, employment change is less employee-friendly for firms from countries with a greater level of individualism and availability of skilled labor (at the $1 \%$ level), but it is more employee-friendly for firms from countries with greater harmony, intellectual autonomy, civil liberties, power distance, individualism, and macro-economic performance as measured by the ratio of the balance of trade to GDP (at the 1\% level). Finally, training is greater for firms from countries with lower levels of corruption and greater political openness to competition as well as firms from countries with greater civil liberties and less skilled labor (at the $10 \%$ level or better). Overall, Table 4 suggests that institutional differences affect employer-employee interdependence.

\footnotetext{
${ }^{3}$ Breaking down Employment Change into its individual components, 53.8\% of companies had an increase in the number of employees and $12.7 \%$ maintained their number of employees during the last three years. For the remaining $33.5 \%$ of sample firms, the decrease in the number of employees was mainly driven by recruitment freezes (23.2\% of the firms), redeployment (21.7\%) and non-renewal of fixed term or temporary contracts (20.5\%). Note that the proportion (percentage) of firms using the various practices is greater than one (100\%) given that some firms used more than one practice to decrease their number of employees.

${ }^{4}$ In terms of the components of the training index (not tabulated), the average number of days of training is 10.06 days per year for management, 10.31 days for professionals, 8.27 days for clerical staff, and 9.42 days for manual laborers. The percentage of annual payroll costs spent on training is equal to $5.05 \%$ on average.
} 
Table 3

Pearson correlation matrix.

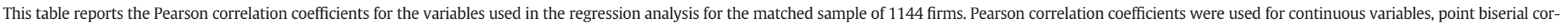
relation coefficients were used for dichotomous variables. ${ }^{* * *}$ and ${ }^{* *}$ denote significance at the $1 \%$ and $5 \%$ level (for the two-tailed test), respectively.

\begin{tabular}{|c|c|c|c|c|c|c|c|c|c|c|c|c|}
\hline & 1 & 2 & 3 & 4 & 5 & 6 & 7 & 8 & 9 & 10 & 11 & 12 \\
\hline 1. CSR dummy & 1.000 & & & & & & & & & & & \\
\hline 2. Employment Change & 0.008 & 1.000 & & & & & & & & & & \\
\hline 3. Training Index & $0.245^{* * *}$ & $-0.150^{* * *}$ & 1.000 & & & & & & & & & \\
\hline 4. Listed dummy & $0.254^{* * *}$ & -0.042 & 0.047 & 1.000 & & & & & & & & \\
\hline 5. Common Law dummy & $-0.163^{* * *}$ & $0.087^{* * *}$ & $-0.088^{* * *}$ & 0.000 & 1.000 & & & & & & & \\
\hline 6. MNE dummy & $0.129^{* * *}$ & -0.029 & $0.117^{* * *}$ & $0.084^{* * * *}$ & 0.000 & 1.000 & & & & & & \\
\hline 7. Size (no. of employees) & $0.096^{* * *}$ & -0.031 & -0.006 & $0.148^{* * *}$ & -0.002 & $0.080^{* * *}$ & 1.000 & & & & & \\
\hline 8. Rating of Profitability & 0.030 & $-0.136^{* * *}$ & $0.146^{* * *}$ & 0.037 & 0.000 & $0.138^{* * *}$ & 0.036 & 1.000 & & & & \\
\hline 9. Rating of Innovation & $0.075^{* *}$ & 0.005 & -0.049 & -0.041 & $0.090^{* * *}$ & $0.133^{* * *}$ & 0.024 & $0.388^{* * *}$ & 1.000 & & & \\
\hline 10. Family dummy & $-0.081^{* * *}$ & -0.005 & -0.001 & $-0.148^{* * *}$ & -0.056 & 0.031 & $-0.090^{* * *}$ & -0.029 & -0.004 & 1.000 & & \\
\hline 11. M\&A dummy & $0.137^{* * *}$ & 0.032 & -0.015 & $0.173^{* * *}$ & 0.040 & $0.150^{* * *}$ & $0.163^{* * *}$ & $0.073^{* *}$ & 0.034 & -0.057 & 1.000 & \\
\hline 12. Investor Rights & $-0.070^{* *}$ & $-0.093^{* * *}$ & $0.173^{* * *}$ & 0.054 & $0.414^{* * *}$ & -0.012 & -0.033 & -0.038 & $0.094^{* * *}$ & -0.021 & $0.083^{* * *}$ & 1.000 \\
\hline 13. GNI per Capita '08 (\$) & $-0.127^{* * *}$ & 0.045 & $-0.118^{* * *}$ & $-0.085^{* * *}$ & $0.141^{* * *}$ & -0.040 & $0.066^{* *}$ & 0.051 & -0.018 & $-0.077^{* *}$ & 0.002 & $-0.119^{* * *}$ \\
\hline 14. GNI Growth Rate & 0.052 & 0.000 & $0.066^{* *}$ & $0.162^{* * *}$ & $-0.217^{* * *}$ & 0.041 & $-0.074^{* *}$ & -0.024 & $-0.080^{* * *}$ & -0.010 & $-0.085^{* * *}$ & 0.019 \\
\hline 15. Absence of Corruption & -0.033 & 0.047 & -0.028 & -0.025 & 0.049 & -0.028 & $0.063^{* *}$ & 0.015 & -0.034 & $-0.063^{* *}$ & $0.112^{* * *}$ & -0.041 \\
\hline 16. Harmony & $0.176^{* * *}$ & $-0.074^{* *}$ & $0.180^{* * *}$ & $-0.064^{* *}$ & $-0.820^{* * *}$ & 0.038 & -0.030 & 0.015 & $-0.065^{* *}$ & 0.050 & 0.015 & $-0.621^{* * *}$ \\
\hline 17. Affective Autonomy & -0.030 & 0.038 & -0.047 & -0.051 & 0.040 & -0.024 & 0.055 & 0.008 & 0.017 & 0.012 & $0.097^{* * *}$ & -0.020 \\
\hline 18. Intellectual Autonomy & $0.069^{* *}$ & -0.039 & 0.021 & -0.058 & $-0.635^{* * *}$ & -0.058 & 0.005 & -0.022 & $-0.081^{* * *}$ & 0.045 & 0.038 & $-0.505^{* * *}$ \\
\hline 19. Egalitarianism & -0.011 & 0.041 & -0.025 & $-0.104^{* * *}$ & -0.047 & 0.047 & 0.007 & $0.074^{* *}$ & 0.050 & -0.013 & $0.095^{* * *}$ & $-0.127^{* * *}$ \\
\hline 20. Civil Liberties & $0.090^{* * * *}$ & $-0.093^{* * *}$ & $0.069^{* *}$ & $0.079^{* *}$ & $-0.101^{* * *}$ & $-0.064^{* *}$ & -0.028 & $-0.085^{* * *}$ & -0.024 & $0.073^{* *}$ & -0.006 & 0.053 \\
\hline 21. Power Distance & 0.012 & -0.046 & 0.032 & -0.043 & $-0.303^{* * *}$ & 0.026 & -0.052 & -0.020 & -0.046 & 0.012 & $-0.118^{* * *}$ & $-0.209^{* * *}$ \\
\hline 22. Individualism & $-0.175^{* * *}$ & $0.111^{* * *}$ & $-0.145^{* * *}$ & -0.056 & $0.714^{* * *}$ & -0.012 & 0.029 & 0.026 & 0.049 & $-0.088^{* * *}$ & 0.057 & $0.465^{* * *}$ \\
\hline 23. Political & 0.028 & 0.029 & 0.035 & -0.002 & -0.014 & -0.001 & $0.074^{* *}$ & 0.020 & -0.031 & -0.055 & $0.149^{* * *}$ & $-0.086^{* * *}$ \\
\hline 24. Labor Market & $-0.150^{* * *}$ & $0.072^{* *}$ & $-0.182^{* * *}$ & 0.019 & $0.443^{* * *}$ & -0.051 & $0.060^{* *}$ & -0.003 & -0.009 & $-0.097^{* * *}$ & -0.011 & $0.254^{* * * *}$ \\
\hline 25. Macroeconomic & 0.019 & 0.043 & 0.025 & -0.015 & -0.250 & 0.025 & -0.026 & 0.029 & -0.003 & -0.056 & $0.068^{* *}$ & $-0.124^{* * *}$ \\
\hline 26. Infrastructure & -0.034 & 0.046 & $-0.065^{* *}$ & -0.003 & $0.151^{* * *}$ & 0.044 & $0.139^{* * *}$ & 0.012 & -0.029 & $-0.066^{* *}$ & $0.070^{* *}$ & -0.042 \\
\hline
\end{tabular}


Table 3 (continued)

\begin{tabular}{|c|c|c|c|c|c|c|c|c|c|c|c|c|c|}
\hline & 13 & 14 & 15 & 16 & 17 & 18 & 19 & 20 & 21 & 22 & 23 & 24 & 25 \\
\hline \multicolumn{14}{|l|}{ 1. CSR dummy } \\
\hline \multicolumn{14}{|l|}{ 2. Employment Change } \\
\hline \multicolumn{14}{|l|}{ 3. Training Index } \\
\hline \multicolumn{14}{|l|}{ 4. Listed dummy } \\
\hline \multicolumn{14}{|l|}{ 5. Common Law dummy } \\
\hline \multicolumn{14}{|l|}{ 6. MNE dummy } \\
\hline \multicolumn{14}{|l|}{ 7. Size (no. of employees) } \\
\hline \multicolumn{14}{|l|}{ 8. Rating of Profitability } \\
\hline \multicolumn{14}{|l|}{ 9. Rating of Innovation } \\
\hline \multicolumn{14}{|l|}{ 10. Family dummy } \\
\hline \multicolumn{14}{|l|}{ 11. M\&A dummy } \\
\hline \multicolumn{14}{|l|}{ 12. Investor Rights } \\
\hline 13. GNI per Capita '08 (\$) & 1.000 & & & & & & & & & & & & \\
\hline 14. GNI Growth Rate & $-0.683^{* * *}$ & 1.000 & & & & & & & & & & & \\
\hline 15. Absence of Corruption & $0.766^{* * *}$ & $-0.583^{* * *}$ & 1.000 & & & & & & & & & & \\
\hline 16. Harmony & $-0.293^{* * *}$ & $0.177^{* * *}$ & -0.013 & 1.000 & & & & & & & & & \\
\hline 17. Affective Autonomy & $0.627^{* * *}$ & $-0.700^{* * * *}$ & $0.745^{* * *}$ & 0.001 & 1.000 & & & & & & & & \\
\hline 18. Intellectual Autonomy & $0.366^{* * *}$ & $-0.328^{* * *}$ & $0.568^{* * *}$ & $0.582^{* * *}$ & $0.613^{* * *}$ & 1.000 & & & & & & & \\
\hline 19. Egalitarianism & $0.563^{* * *}$ & $-0.624^{* * *}$ & $0.654^{* * *}$ & $0.164^{* * *}$ & $0.717^{* * *}$ & $0.466^{* * * *}$ & 1.000 & & & & & & \\
\hline 20. Civil Liberties & $-0.564^{* * *}$ & $0.269^{* * *}$ & $-0.689^{* * *}$ & $0.034^{* * *}$ & $-0.400^{* * *}$ & $-0.300^{* * *}$ & $-0.503^{* * *}$ & 1.000 & & & & & \\
\hline 21. Power Distance & $-0.507^{* * *}$ & $0.508^{* * *}$ & $-0.705^{* * *}$ & $0.270^{* * *}$ & $-0.699 * * *$ & $-0.184^{* * *}$ & $-0.460^{* * *}$ & $0.407^{* * *}$ & 1.000 & & & & \\
\hline 22. Individualism & $0.638^{* * *}$ & $-0.597^{* * *}$ & $0.551^{* * *}$ & $-0.611^{* * *}$ & $0.478^{* * *}$ & $-0.155^{* * *}$ & $0.480^{* * *}$ & $-0.471^{* * *}$ & $-0.557^{* * * *}$ & 1.000 & & & \\
\hline 23. Political & $0.604^{* * *}$ & $-0.477^{* * *}$ & $0.918^{* * *}$ & $0.089^{* * *}$ & $0.690^{* * *}$ & $0.482^{* * *}$ & $0.674^{* * *}$ & $-0.533^{* * *}$ & $-0.762^{* * *}$ & $0.451^{* * *}$ & 1.000 & & \\
\hline 24. Labor Market & $0.744^{* * *}$ & $-0.395^{* * *}$ & $0.541^{* * * *}$ & $-0.666^{* * *}$ & $0.328^{* * *}$ & 0.025 & 0.112 & $-0.452^{* * *}$ & $-0.394^{* * *}$ & $0.649^{* * *}$ & $0.330^{* * *}$ & 1.000 & \\
\hline 25. Macroeconomic & 0.034 & $0.262^{* * *}$ & $0.382^{* * *}$ & $0.318^{* * *}$ & $0.122^{* * *}$ & $0.299^{* * *}$ & $0.321^{* * *}$ & $-0.312^{* * *}$ & $-0.228^{* * *}$ & -0.036 & $0.496 * * *$ & 0.006 & 1.000 \\
\hline 26. Infrastructure & $0.779^{* * *}$ & $-0.549^{* * *}$ & $0.819^{* * * *}$ & $-0.248^{* * *}$ & $0.707^{* * * *}$ & $0.362^{* * * *}$ & $0.512^{* * *}$ & $-0.562^{* * *}$ & $-0.631^{* * *}$ & $0.559^{* * * *}$ & $0.763 * * *$ & $0.644^{* * *}$ & $0.106^{* * * *}$ \\
\hline
\end{tabular}

25. Macroeconom

0.779

$0.262^{* * * *}$

$0.318^{* * *}$
$-0.248^{* *}$

$0.707^{* * *}$

$0.299^{* * *}$

$0.512^{* * *}$

$-0.312^{* * *}$

$-0.631^{* * *}$ 
Table 4

Listed firms, MNEs, institutional setting, CSR statement, and employer-employee interdependence.

This table reports the regression results for the matched sample of 1144 firms. The dependent variables are: (1) CSR dummy equals one if the firm has a CSR code, and zero otherwise. (2) Adjusted Employment Change is equal to 0 if there have been no restrictive employment practices and the number of employees has increased over the last three years; 1 if there have been no restrictive employment practices and the number of employees has not changed over the last three year; 2 if there has been a recruitment freeze; 3 if there has been redeployment; 4 if there have been voluntary redundancies; 5 if there have been early retirements; 6 if there has been no renewal of fixed/temporary contracts; 7 if there has been outsourcing; and 8 if there have been compulsory redundancies. Adj. Employment Change is adjusted by firm size, using the number of employees. (3) Training Index ranges from zero to five, and it is equal to the sum of the four dummy variables related to High Number of Days per Year Training (as a percentage of staff turnover) per category of employee plus the High Percentage Annual Payroll Costs Spent on Training dummy. The explanatory variables are defined in the Appendix. ***, **, and * denote significance at the $1 \%, 5 \%$, and $10 \%$ level (for the two-tailed test), respectively. Standard-errors are in italic.

\begin{tabular}{|c|c|c|c|c|c|c|}
\hline & \multicolumn{2}{|c|}{ CSR dummy } & \multicolumn{2}{|c|}{ Adj. Employment Change } & \multicolumn{2}{|c|}{ Training Index } \\
\hline & $(1 \mathrm{a})$ & $(1 \mathrm{~b})$ & $(2 a)$ & $(2 \mathrm{~b})$ & $(3 a)$ & $(3 \mathrm{~b})$ \\
\hline \multirow[t]{2}{*}{ Constant } & $-1.894^{* * *}$ & 1.885 & $0.084^{* * *}$ & $0.090^{* * *}$ & 0.125 & -1.776 \\
\hline & 0.447 & 1.714 & 0.014 & 0.033 & 0.369 & 1.335 \\
\hline \multirow[t]{2}{*}{ CSR dummy } & & & 0.001 & 0.001 & $0.488^{* * *}$ & $0.473^{* * *}$ \\
\hline & & & 0.003 & 0.003 & 0.121 & 0.127 \\
\hline \multirow[t]{2}{*}{ Listed dummy } & $0.936^{* * *}$ & $0.901^{* * *}$ & $-0.006^{* *}$ & $-0.006^{* *}$ & $0.275^{* *}$ & $0.230^{*}$ \\
\hline & 0.136 & 0.146 & 0.003 & 0.003 & 0.109 & 0.114 \\
\hline \multirow[t]{2}{*}{ Common Law dummy } & $-0.778^{* * *}$ & $-0.339^{* *}$ & $0.010^{* * *}$ & $0.011^{* *}$ & $-0.192^{*}$ & $-0.263^{*}$ \\
\hline & 0.136 & 0.160 & 0.004 & 0.005 & 0.106 & 0.155 \\
\hline \multirow[t]{2}{*}{ MNE dummy } & $0.327^{* *}$ & $0.278^{*}$ & 0.002 & 0.002 & $0.295^{* *}$ & $0.323^{* *}$ \\
\hline & 0.147 & 0.157 & 0.003 & 0.003 & 0.127 & 0.132 \\
\hline \multirow[t]{2}{*}{ Ln Size } & $0.219^{* * *}$ & $0.197^{* * *}$ & $-0.011^{* * *}$ & $-0.011^{* * *}$ & 0.004 & -0.029 \\
\hline & 0.042 & 0.046 & 0.001 & 0.001 & 0.036 & 0.039 \\
\hline \multirow[t]{2}{*}{ Rating of Profitability } & 0.132 & 0.104 & $-0.003^{*}$ & $-0.003^{*}$ & $0.112^{*}$ & $0.125^{*}$ \\
\hline & 0.082 & 0.086 & 0.002 & 0.002 & 0.068 & 0.070 \\
\hline \multirow{2}{*}{ Rating of Innovation } & $0.281^{* * *}$ & $0.274^{* * *}$ & $-0.003^{*}$ & $-0.003^{*}$ & $0.141^{* *}$ & $0.129^{* *}$ \\
\hline & 0.079 & 0.082 & 0.002 & 0.002 & 0.065 & 0.066 \\
\hline \multirow[t]{2}{*}{ Family dummy } & $-0.305^{*}$ & $-0.310^{*}$ & 0.003 & 0.003 & -0.067 & -0.090 \\
\hline & 0.162 & 0.170 & 0.003 & 0.003 & 0.142 & 0.147 \\
\hline \multirow[t]{2}{*}{ M\&A dummy } & 0.183 & 0.123 & 0.003 & 0.004 & -0.037 & -0.096 \\
\hline & 0.143 & 0.151 & 0.003 & 0.003 & 0.122 & 0.126 \\
\hline \multirow[t]{2}{*}{ Investor Rights } & & $1.247^{*}$ & & $-0.018^{*}$ & & 0.484 \\
\hline & & 0.678 & & 0.011 & & 0.604 \\
\hline \multirow[t]{2}{*}{ Ln GNI } & & $-0.425^{* * *}$ & & 0.002 & & $-0.153^{*}$ \\
\hline & & 0.152 & & 0.003 & & 0.093 \\
\hline \multirow[t]{2}{*}{ GNI Growth Rate } & & $-0.267^{* * *}$ & & $-0.002^{*}$ & & -0.050 \\
\hline & & 0.073 & & 0.001 & & 0.062 \\
\hline \multirow[t]{2}{*}{ Absence of Corruption } & & $1.861^{*}$ & & 0.020 & & $2.443^{* *}$ \\
\hline & & 1.057 & & 0.023 & & 1.126 \\
\hline Harmony & & $11.838^{* *}$ & & $-0.322^{* * *}$ & & 6.208 \\
\hline & & 5.809 & & 0.112 & & 4.886 \\
\hline Affective autonomy & & 2.121 & & 0.009 & & 1.416 \\
\hline & & 1.842 & & 0.035 & & 1.665 \\
\hline Intellectual Autonomy & & $9.431^{*}$ & & $-0.264^{* * *}$ & & 4.738 \\
\hline & & 5.290 & & 0.101 & & 4.434 \\
\hline Egalitarianism & & $3.856^{* *}$ & & -0.057 & & -1.211 \\
\hline & & 1.959 & & 0.035 & & 1.685 \\
\hline Civil Liberties & & 0.718 & & $-0.026^{* * *}$ & & $0.708^{*}$ \\
\hline & & 0.539 & & 0.009 & & 0.407 \\
\hline Power Distance & & -0.003 & & $-0.002^{* * *}$ & & -0.012 \\
\hline & & 0.041 & & 0.001 & & 0.038 \\
\hline Individualism & & $-0.088^{*}$ & & $0.004^{* * *}$ & & -0.048 \\
\hline & & 0.050 & & 0.001 & & 0.046 \\
\hline Political & & $8.867^{* *}$ & & -0.036 & & $8.143^{* * * *}$ \\
\hline & & 3.489 & & 0.065 & & 3.098 \\
\hline Labor Market & & $-3.904^{* *}$ & & $0.116^{* * *}$ & & $-2.180^{*}$ \\
\hline & & 1.982 & & 0.037 & & 1.198 \\
\hline Macroeconomic & & 0.134 & & $-0.038^{* * *}$ & & -0.025 \\
\hline & & 0.712 & & 0.013 & & 0.591 \\
\hline Infrastructure & & 0.490 & & 0.014 & & 0.432 \\
\hline & & 0.515 & & 0.009 & & 0.426 \\
\hline Industry Effects & Yes & Yes & Yes & Yes & Yes & Yes \\
\hline $\mathrm{N}$ & 1144 & 1144 & 1046 & 1046 & 370 & 370 \\
\hline Pseudo R2 (Adj. R2) & 0.133 & 0.172 & $(0.180)$ & $(0.179)$ & 0.043 & 0.065 \\
\hline LR chi2 (F-statistic) & 211.150 & 271.920 & $(9.350)$ & $(6.850)$ & 54.780 & 82.990 \\
\hline Prob. & 0.000 & 0.000 & 0.000 & 0.000 & 0.009 & 0.001 \\
\hline
\end{tabular}


Table 5

CSR statement, employer-employee interdependence, and the moderating effects of public listing, multinational activities and institutional setting.

This table reports the regression results for the matched sample of 1144 firms. The dependent variables are: (1) CSR dummy, (2) Adjusted Employment Change, and (3) Training Index. Regressions (4a), (5a), and (6a) control for the differential effect of listing status on the association between employer-employee interdependence and Common Law dummy. Regressions (4b), (5b), and (6b) control for the differential effect of MNE status on the association between employer-employee interdependence and Common Law dummy. Regressions (4c), (5c), and (6c) compare the differential effects of MNE and listing status on the association between employer-employee interdependence and Common Law dummy in the combined model. The explanatory variables are defined in the Appendix. ***, **, and * denote significance at the $1 \%, 5 \%$, and $10 \%$ level (for the two-tailed test), respectively. Standard-errors are in italic.

\begin{tabular}{|c|c|c|c|c|c|c|c|c|c|}
\hline & \multicolumn{3}{|c|}{ CSR dummy } & \multicolumn{3}{|c|}{ Adjusted Employment Change } & \multicolumn{3}{|c|}{ Training Index } \\
\hline & $(4 a)$ & $(4 b)$ & $(4 c)$ & $(5 a)$ & $(5 b)$ & $(5 c)$ & $(6 a)$ & $(6 b)$ & $(6 c)$ \\
\hline \multirow[t]{2}{*}{ Constant } & 1.730 & 1.883 & 1.746 & $0.090^{* * *}$ & $0.090^{* * *}$ & $0.091^{* * *}$ & 1.818 & 1.770 & 1.627 \\
\hline & 1.727 & 1.714 & 1.729 & 0.033 & 0.033 & 0.033 & 1.337 & 1.336 & 1.345 \\
\hline \multirow[t]{2}{*}{ CSR dummy } & & & & 0.001 & 0.001 & 0.001 & $0.479^{* * *}$ & $0.466^{* * *}$ & $0.495^{* * *}$ \\
\hline & & & & 0.003 & 0.003 & 0.003 & 0.128 & 0.127 & 0.129 \\
\hline \multirow[t]{2}{*}{ Listed dummy } & $1.042^{* * *}$ & $0.901^{* * *}$ & $0.905^{* * *}$ & $-0.004^{* *}$ & $-0.004^{* *}$ & $-0.004^{* *}$ & $0.165^{*}$ & $0.169^{*}$ & $0.154^{*}$ \\
\hline & 0.214 & 0.146 & 0.275 & 0.002 & 0.002 & 0.002 & 0.089 & 0.090 & 0.087 \\
\hline \multirow[t]{2}{*}{ Common Law dummy } & $-0.144^{* *}$ & $-0.329^{*}$ & $-0.298^{* *}$ & $0.012^{* *}$ & $0.012^{* *}$ & $0.011^{* *}$ & $-0.212^{* *}$ & -0.050 & $-0.162^{*}$ \\
\hline & 0.067 & 0.190 & 0.141 & 0.005 & 0.005 & 0.005 & 0.098 & 0.078 & 0.098 \\
\hline \multirow[t]{2}{*}{ MNE dummy } & $0.278^{*}$ & $0.292^{*}$ & 0.132 & 0.002 & 0.001 & 0.001 & $0.328^{* *}$ & $0.489^{* * *}$ & $0.309^{* * *}$ \\
\hline & 0.157 & 0.170 & 0.294 & 0.003 & 0.004 & 0.006 & 0.132 & 0.181 & 0.106 \\
\hline \multirow[t]{2}{*}{ Common Law $\times$ Listed dummy } & -0.262 & & -0.042 & 0.002 & & -0.001 & -0.192 & & -0.116 \\
\hline & 0.289 & & 0.379 & 0.005 & & 0.007 & 0.240 & & 0.324 \\
\hline \multirow[t]{2}{*}{ Common Law $\times$ MNE dummy } & & -0.027 & 0.239 & & 0.005 & 0.004 & & 0.080 & -0.125 \\
\hline & & 0.288 & 0.410 & & 0.005 & 0.008 & & 0.060 & 0.088 \\
\hline \multirow[t]{2}{*}{ Listed dummy $\times$ MNE dummy } & & & $0.320^{* *}$ & & & $-0.002^{*}$ & & & $0.329 *$ \\
\hline & & & 0.159 & & & 0.001 & & & 0.197 \\
\hline \multirow[t]{2}{*}{ Common Law $\times$ MNE $\times$ Listed dummy } & & -0.503 & & & 0.000 & & & 0.184 & \\
\hline & & & 0.561 & & & 0.010 & & & 0.240 \\
\hline Control variables & Yes & Yes & Yes & Yes & Yes & Yes & Yes & Yes & Yes \\
\hline Industry Effects & Yes & Yes & Yes & Yes & Yes & Yes & Yes & Yes & Yes \\
\hline $\mathrm{N}$. & 1144 & 1144 & 1144 & 1046 & 1046 & 1046 & 370 & 370 & 370 \\
\hline Pseudo R2 (Adj. R2) & 0.172 & 0.172 & 0.173 & $(0.179)$ & $(0.179)$ & $(0.177)$ & 0.065 & 0.066 & 0.069 \\
\hline LR chi2 (F-statistic) & 272.750 & 271.930 & 273.600 & $(6.680)$ & $(6.700)$ & $(6.220)$ & 83.620 & 84.770 & 88.120 \\
\hline Prob. & 0.000 & 0.000 & 0.000 & 0.000 & 0.000 & 0.000 & 0.000 & 0.000 & 0.000 \\
\hline
\end{tabular}

Table 5 investigates how common law may affect the impact of listing status and MNE status on the firm's employer-employee interdependence. It also investigates how common law might influence the effect of the interaction between MNE status and listed status on employer-employee interdependence. Regressions (4a), (5a), and (6a) examine the impact of the listing status for firms from common law countries with that for firms from civil law countries. The regression results confirm the findings in Table 4, and indicate that firms from common law countries are less likely to have a CSR statement, that they engage in

Table 6

CSR statement, employer-employee interdependence, and institutional setting: focusing on emerging and transitional economies

This table reports the regression results for the matched sample of 1144 firms. The dependent variables are CSR dummy (Models (7a and 7b)), Adjusted Employment Change (regressions (8a) and (8b)), and Training Index (regressions (9a) and (9b)). Regressions are run on the sub-sample of firms excluding emerging and transitional countries (regressions (7a), (8a), and (9a)) and on the sub-sample of emerging and transitional countries (regressions (7b), (8b), and (9b)). All variables are explained in the Appendix. ***, **, and * denote significance at the $1 \%, 5 \%$, and $10 \%$ level (for the two-tailed test), respectively. Standard-errors are in italic.

\begin{tabular}{|c|c|c|c|c|c|c|}
\hline & \multicolumn{3}{|c|}{ Exc. emerging \& transitional economies } & \multicolumn{3}{|c|}{ Emerging \& transitional economies } \\
\hline & CSR dummy & Adj. Employment Change & Training Index & CSR dummy & Adj. Employment Change & Training Index \\
\hline & $(7 a)$ & $(8 a)$ & $(9 a)$ & (7b) & $(8 b)$ & (9b) \\
\hline \multirow[t]{2}{*}{ Constant } & 6.935 & -10.919 & $18.346^{*}$ & 4.461 & -19.703 & -48.573 \\
\hline & 8.245 & 10.887 & 10.561 & 2.564 & 27.645 & 197.153 \\
\hline \multirow[t]{2}{*}{ CSR dummy } & & 0.152 & $0.458^{* * *}$ & & 0.005 & 0.419 \\
\hline & & 0.251 & 0.144 & & 0.567 & 0.442 \\
\hline \multirow[t]{2}{*}{ Listed dummy } & $0.874^{* * *}$ & $-0.329^{* *}$ & $0.292^{* *}$ & $1.545^{* * *}$ & 0.564 & $0.133^{*}$ \\
\hline & 0.166 & 0.156 & 0.145 & 0.452 & 0.539 & 0.075 \\
\hline \multirow[t]{2}{*}{ Common Law dummy } & $-0.264^{*}$ & $0.228^{*}$ & $-5.591^{*}$ & & & \\
\hline & 0.146 & 0.123 & 3.121 & & & \\
\hline \multirow[t]{2}{*}{ MNE dummy } & $0.174^{* *}$ & -0.065 & $0.344^{* *}$ & $1.239^{* *}$ & 0.940 & $0.954^{* *}$ \\
\hline & 0.088 & 0.260 & 0.152 & 0.461 & 0.688 & 0.390 \\
\hline Control variables & Yes & Yes & Yes & Yes & Yes & Yes \\
\hline Industry Effects & Yes & Yes & Yes & Yes & Yes & Yes \\
\hline $\mathrm{N}$. & 928 & 846 & 295 & 216 & 200 & 75 \\
\hline Pseudo R2 & 0.176 & 0.083 & 0.086 & 0.346 & 0.103 & 0.177 \\
\hline LR chi2 (F-statistic) & 226.770 & 2.960 & 87.590 & 99.670 & 1.700 & 45.890 \\
\hline Prob. & 0.000 & 0.017 & 0.000 & 0.000 & 0.000 & 0.000 \\
\hline
\end{tabular}


more employee-unfriendly employment change, and invest less in training (at the 5\% level), and this common law effect is not significantly different for listed firms. Our results suggest that listed firms - whatever the legal family of their country of origin - are more likely to be subject to public scrutiny.

Regressions (4b), (5b), and (6b) examine whether there is a differential effect of the MNE status for firms from common law countries. The regression results confirm our previous findings from Table 4, and indicate no significant difference in the effect of MNE status on the likelihood of the firm having a CSR statement and greater employer-employee interdependence across legal origins. This suggests that the MNE effect we observe holds across legal origins.

Finally, regressions (4c), (5c), and (6c) investigate whether there is a differential effect on the likelihood of a CSR statement and greater employer-employee interdependence of i) listed MNEs and ii) listed MNEs from common law countries. Interestingly, the regressions suggest that listed MNEs are more likely to have a CSR statement as well as greater employer-employee interdependence (at the $10 \%$ level or better). However again, this effect does not vary across legal families.

To sum up our results from Table 5, listed MNEs from civil law countries have the highest likelihood to have a CSR statement and the highest likelihood to have greater employer-employee interdependence whereas non-listed non-MNEs from common law countries have the lowest such likelihood. This suggests that both a public listing and MNE status expose firms to reputation and market share considerations, thus pushing them to adopt responsible employee management practices. As to the control variables, similar patterns emerge to those in Table 4.

\section{Robustness checks}

\subsection{Emerging and transitional economies}

But, what about possible differences between mature economies and those of more peripheral or transitional status? As a robustness test, we divide our matched sample into two sub-samples of firms from mature economies and those from emerging or transitional economies, i.e. those from South Africa, ex-communist Eastern European and Mediterranean civil law countries. In Table 6, we then repeat the regressions from Table 4 for the two sub-samples. As our sub-sample of firms from emerging and transitional economies is entirely composed of firms from common law countries, we cannot include Common Law dummy in regressions (7b), (8b), and (9b).

Table 6 provides for both sub-samples support for our Hypotheses 1, 2, and 3, and confirms the role played by a public listing, MNE status and civil law countries in increasing the likelihood of having a CSR statement and having greater employer-employee interdependence (regressions (7a), (8a) and (9a)). For the sub-sample of firms from emerging and transitional economies, both the likelihood of a CSR statement (regression (7b)) and more investment in training (regression (9b)) is positively and significantly related to Listed dummy and MNE dummy (at the $10 \%$ level or better, and at the $5 \%$ level, respectively), whereas there is no significant effect of these variables on Adjusted Employment Change. Overall, our findings suggest that the results for emerging and transitional economies are slightly less significant than the ones for firms from mature economies. Indeed, listed firms are more likely to be subject to public scrutiny in any context, but it appears that such scrutiny is more likely to have positive effects

Table 7

CSR statement, employer-employee interdependence, institutional setting and investor rights.

This table reports the regressions results for the matched sample of 1144 firms. The dependent variables are CSR dummy (regression (10)), Adjusted Employment Change (regression (11)), and Training Index (regression (12)). All variables are explained in the Appendix. ***,*, and * denote significance at the $1 \%, 5 \%$, and $10 \%$ level (for the two-tailed test), respectively. Standard-errors are in italic. (a) denotes that the difference between the two coefficients in question is statistically different at the $1 \%$ level. (a) denotes that the difference between the two coefficients in question is statistically different at the $1 \%$ level.

\begin{tabular}{|c|c|c|c|}
\hline & CSR dummy & Adj. Employment Change & Training Index \\
\hline & $(10)$ & $(11)$ & $(12)$ \\
\hline \multirow[t]{2}{*}{ Constant } & 1.706 & $0.075^{* *}$ & -1.495 \\
\hline & 1.934 & 0.038 & 1.485 \\
\hline \multirow[t]{2}{*}{ CSR dummy } & & 0.001 & $0.477^{* * *}$ \\
\hline & & 0.003 & 0.127 \\
\hline \multirow[t]{2}{*}{ Listed dummy } & $0.877^{* * *}$ & $-0.005^{*}$ & $0.234^{*}$ \\
\hline & 0.145 & 0.003 & 0.125 \\
\hline \multirow[t]{2}{*}{ MNE dummy } & $0.297^{* *}$ & 0.002 & $0.338^{* * *}$ \\
\hline & 0.156 & 0.003 & 0.132 \\
\hline \multirow[t]{2}{*}{ Common Law } & $-2.112^{*}$ & $0.065^{*}$ & $-4.236^{* *}$ \\
\hline & 1.246 & 0.037 & 2.119 \\
\hline \multirow[t]{2}{*}{ Investor Rights $\times$ Common Law } & $2.591^{*(a)}$ & 0.030 & $4.565^{* *}$ \\
\hline & 1.511 & 0.049 & 2.211 \\
\hline \multirow[t]{2}{*}{ Investor Rights $\times$ Civil Law } & $0.308^{*}(\mathrm{a})$ & $-0.030^{* *}$ & 0.455 \\
\hline & 0.173 & 0.015 & 0.786 \\
\hline Control variables & Yes & Yes & Yes \\
\hline Industry Effects & Yes & Yes & Yes \\
\hline $\mathrm{N}$ & 1144 & 1046 & 370 \\
\hline Pseudo R2 (Adj. R2) & 0.168 & $(0.177)$ & 0.068 \\
\hline LR chi2 (F-statistic) & 267.120 & $(6.760)$ & 86.480 \\
\hline Prob. & 0.000 & 0.000 & 0.000 \\
\hline
\end{tabular}


in civil law countries, where stakeholder rights are stronger under the law, and more can be done to hold 'irresponsible' companies to account. Finally, while Tables 4 and 5 did not suggest that a CSR statement results in more employee-friendly employment practices, Table 6 suggests a strong positive correlation between the two (at the $5 \%$ level) for the case of mature economies. This provides support for Hypothesis 4.

Furthermore, South Africa and Japan may be considered as hybrid systems, and may thus be excluded from common law and civil law categorizations. Although most of the recent studies consider South Africa as a common law country and Japan as a civil

Table 8

CSR statement, employer-employee interdependence in the un-matched sample.

This table reports the regressions for the un-matched sample of 4165 firms. The dependent variables are CSR dummy (regressions (13a) and (13b)), Adjusted Employment Change (regressions (14a) and (14b)), and Training Index (regressions (15a) and (15b)). All variables are explained in the Appendix. ***, **, and * denote significance at the $1 \%, 5 \%$, and $10 \%$ level (for the two-tailed test), respectively. Standard-errors are in italic. (a) Denotes that the difference between the two coefficients in question is statistically different at the $1 \%$ level.

\begin{tabular}{|c|c|c|c|c|c|c|}
\hline & \multicolumn{2}{|c|}{ CSR dummy } & \multicolumn{2}{|c|}{ Adj. Employment Change } & \multicolumn{2}{|c|}{ Training Index } \\
\hline & $(13 a)$ & $(13 b)$ & $(14 a)$ & $(14 b)$ & $(15 a)$ & $(15 b)$ \\
\hline \multirow[t]{2}{*}{ Constant } & $-3.186^{* * *}$ & $-3.984^{* * *}$ & $0.114^{* * *}$ & $0.145^{* * *}$ & $-0.382^{* *}$ & $-1.820^{* * *}$ \\
\hline & 0.222 & 0.849 & 0.011 & 0.028 & 0.128 & 0.500 \\
\hline \multirow[t]{2}{*}{ CSR dummy } & & & $0.006^{* *}$ & $0.006^{* *}$ & $0.292^{* * *}$ & $0.261^{* * *}$ \\
\hline & & & 0.002 & 0.002 & 0.044 & 0.046 \\
\hline \multirow[t]{2}{*}{ Listed dummy } & $0.485^{* * *}$ & $0.478^{* * *}$ & $-0.006^{* *}$ & $-0.003^{*}$ & $0.066^{* *}$ & $0.059^{*}$ \\
\hline & 0.074 & 0.080 & 0.002 & 0.002 & 0.030 & 0.035 \\
\hline \multirow[t]{2}{*}{ Common Law dummy } & $-0.301^{* * *}$ & $-0.315^{* *}$ & $0.008^{* *}$ & $0.010^{* *}$ & $-0.092^{*}$ & $-0.075^{*}$ \\
\hline & 0.097 & 0.156 & 0.003 & 0.005 & 0.047 & 0.044 \\
\hline \multirow[t]{2}{*}{ MNE dummy } & $0.293^{* * *}$ & $0.343^{* * *}$ & $-0.005^{* *}$ & $-0.004^{*}$ & $0.070^{*}$ & $0.136^{* * *}$ \\
\hline & 0.077 & 0.083 & 0.003 & 0.003 & 0.042 & 0.048 \\
\hline \multirow[t]{2}{*}{ Ln Size } & $0.290^{* * *}$ & $0.235^{* * *}$ & $-0.017^{* * *}$ & $-0.016^{* * *}$ & $0.038^{* * *}$ & $0.037^{* *}$ \\
\hline & 0.024 & 0.026 & 0.001 & 0.001 & 0.014 & 0.015 \\
\hline \multirow[t]{2}{*}{ Rating of Profitability } & 0.001 & 0.025 & $-0.189^{* * *}$ & $-0.198^{* * *}$ & 0.020 & $0.034^{*}$ \\
\hline & 0.041 & 0.042 & 0.022 & 0.022 & 0.024 & 0.020 \\
\hline \multirow[t]{2}{*}{ Rating of Innovation } & $0.170^{* * *}$ & $0.199^{* * *}$ & -0.001 & -0.001 & $0.093^{* * *}$ & $0.116^{* * *}$ \\
\hline & 0.037 & 0.038 & 0.001 & 0.001 & 0.022 & 0.022 \\
\hline \multirow[t]{2}{*}{ Family dummy } & $-0.334^{* * *}$ & $-0.457^{* * *}$ & $0.006^{* *}$ & $0.006^{* *}$ & -0.037 & -0.031 \\
\hline & 0.082 & 0.086 & 0.003 & 0.003 & 0.048 & 0.049 \\
\hline \multirow[t]{2}{*}{ M\&A dummy } & -0.074 & -0.074 & 0.002 & 0.003 & 0.003 & 0.034 \\
\hline & 0.072 & 0.076 & 0.002 & 0.002 & 0.044 & 0.045 \\
\hline \multirow[t]{2}{*}{ Investor Rights } & & $0.900^{* *}$ & & -0.013 & & -0.166 \\
\hline & & 0.352 & & 0.010 & & 0.189 \\
\hline \multirow[t]{2}{*}{ Ln GNI } & & 0.030 & & -0.002 & & $-0.138^{* * *}$ \\
\hline & & 0.075 & & 0.002 & & 0.045 \\
\hline \multirow[t]{2}{*}{ GNI Growth rate } & & $-0.161^{* * *}$ & & $-0.004^{* * *}$ & & $-0.047^{* * *}$ \\
\hline & & 0.031 & & 0.001 & & 0.018 \\
\hline \multirow[t]{2}{*}{ Absence of Corruption } & & $1.831^{* * *}$ & & -0.008 & & 0.003 \\
\hline & & 0.675 & & 0.020 & & 0.403 \\
\hline Harmony & & $10.624^{* * * *}$ & & $-0.200^{* * *}$ & & 0.793 \\
\hline & & 1.355 & & 0.040 & & 0.752 \\
\hline Affective Autonomy & & -0.706 & & -0.006 & & $-1.604^{* * *}$ \\
\hline & & 0.619 & & 0.019 & & 0.363 \\
\hline Intellectual Autonomy & & $6.233^{* * *}$ & & $-0.149^{* * *}$ & & 0.038 \\
\hline & & 0.983 & & 0.030 & & 0.547 \\
\hline Egalitarianism & & $1.732^{* *}$ & & $-0.073^{* * *}$ & & $-3.060^{* * *}$ \\
\hline & & 0.804 & & 0.024 & & 0.489 \\
\hline Civil Liberties & & $1.080^{* * *}$ & & -0.005 & & $0.511^{* * *}$ \\
\hline & & 0.242 & & 0.008 & & 0.142 \\
\hline Power Distance & & $0.022^{*}$ & & $-0.001^{* * *}$ & & 0.010 \\
\hline & & 0.012 & & 0.000 & & 0.007 \\
\hline Individualism & & $-0.074^{* * *}$ & & $0.002^{* * *}$ & & $-0.008^{*}$ \\
\hline & & 0.009 & & 0.000 & & 0.005 \\
\hline Political & & $9.650^{* * * *}$ & & -0.076 & & -1.110 \\
\hline & & 2.053 & & 0.061 & & 1.189 \\
\hline Labor Market & & $-3.148^{* * *}$ & & $0.052^{* * *}$ & & -0.045 \\
\hline & & 0.451 & & 0.014 & & 0.293 \\
\hline Macroeconomic & & -0.158 & & $-0.027^{* * *}$ & & $-0.414^{* *}$ \\
\hline & & 0.300 & & 0.009 & & 0.184 \\
\hline Infrastructure & & $0.489^{* *}$ & & 0.005 & & $-0.335^{* * *}$ \\
\hline & & 0.223 & & 0.007 & & 0.118 \\
\hline Industry Effects & Yes & Yes & Yes & Yes & Yes & Yes \\
\hline $\mathrm{N}$. & 4165 & 4165 & 4165 & 4165 & 2639 & 2639 \\
\hline Pseudo R2 (Adj. R2) & 0.073 & 0.119 & $(0.136)$ & $(0.142)$ & 0.016 & 0.028 \\
\hline LR chi2 (F-statistic) & 399.120 & 645.270 & $(28.220)$ & $(19.180)$ & 145.490 & 257.810 \\
\hline Prob. & 0.000 & 0.000 & 0.000 & 0.000 & 0.000 & 0.000 \\
\hline
\end{tabular}


law country, each of these countries has some legal codes that are based in civil law and others in common law, with laws from different legal traditions applying to e.g. contract law and company law. Although not tabulated, we have repeated our tests in Table 4, excluding both Japan and South Africa, and the results remain consistent with the findings from Table 4.

\subsection{Employer-employee interdependence, institutional setting, and investor rights}

Our descriptive statistics in Table 2 reveal that common law countries score significantly higher on the investor rights index, which itself has a positive effect on the likelihood of a CSR statement and a negative effect on employment change. As a robustness test, in Table 7 we examine whether there is a differential effect of the legal origin on the association between investor rights on the one side and the likelihood of a CSR statement or employer-employee interdependence on the other side. The results in Table 7 confirm our findings from Table 4. The likelihood of having a CSR statement is lower for firms from common law countries. In addition, such firms are more likely to engage in employment change practices that are perceived to be less employee friendly. Such firms also invest less in training. However, focusing on the interaction between the investor rights index and legal origin, regression (10) suggests that firms are more likely to have a CSR statement if they are from countries with stronger investor rights, across both legal families (at the 10\% level). Nevertheless, this effect is significantly greater for firms from common law countries (at the 1\% level). Regression (11) indicates that firms are less likely to engage in more employee-unfriendly employment change if they are from civil law countries with stronger investor rights (at the $5 \%$ level). Finally, regression (12) indicates that training is positively related to the strength of investor rights in common law countries (at the $5 \%$ level).

\subsection{Employer-employee interdependence in the un-matched sample}

Table 8 is the equivalent of Table 4, but is based on the full, un-matched sample. All the regressions in the table provide further support for the validity of Hypotheses 1, 2 and 3. Regressions (13a) and (13b) suggest that CSR statements are more likely for listed firms and MNEs (at the 1\% level), but they are less likely for firms from common law countries (at the 5\% level or better). Further, employment change is more employee-friendly in listed firms and MNEs (at the $10 \%$ level or better), but it is less employee-friendly in firms from common law countries (at the 5\% level). Finally, training is greater in listed firms and MNEs (at the $10 \%$ level or better), but there is less of it in firms from common law countries (at the $10 \%$ level).

Moreover, we find a positive and significant coefficient on CSR dummy in regressions (15a) and (15b), which confirms the existence of a positive correlation between a CSR statement and investment in staff training. However, somewhat surprisingly we also find a positive rather than negative coefficient on CSR dummy in regressions (14a) and (14b), which would suggest that firms with a CSR statement engage in more employee-unfriendly employment change. This is in direct contrast to Hypothesis 4.

Why would this be the case? As a reminder, Table 8 is based on the un-matched sample, contrary to all the previous tables (which, apart from Table 6, did not suggest a correlation between a CSR statement and employment change), and is therefore based on a sample including the much larger listed firms (which are dropped from the matched sample due to the absence of equally large non-listed firms). ${ }^{5}$ Further investigations (not tabulated) suggest that, if size is excluded from regressions (14a) and (14b), the coefficient on CSR dummy becomes negative and significant (at the $1 \%$ level), which is in line with Hypothesis 4. The coefficient on CSR dummy is also negative and significant (at the $1 \%$ level) if we include the interaction between CSR dummy and Size. The coefficient on the latter is positive and significant and the coefficient on Size is negative and significant (at the 1\% level). This suggests that firms with a CSR statement engage in more employee-friendly employment change, but that this correlation is lower for larger firms. This supports Wickert et al.'s (2016) theoretical prediction that large firms are more likely to 'talk CSR' (i.e. to communicate about CSR) as this is relatively cheap, but less likely to 'walk CSR' (i.e. to engage in actual CSR), which is relatively costly given their greater complexity.

Although not tabulated, in further investigations, we repeat our interaction analysis from Table 5 for the un-matched sample. We find that listed firms from civil law countries are more likely to have a CSR statement and invest more in training (at the $1 \%$ and $10 \%$ level, respectively). Moreover, listed MNEs from civil law countries are more likely to have a CSR statement and more training activities and less likely to have an employee-unfriendly change in their employment figures (at the $1 \%, 5 \%$, and $10 \%$ level, respectively).

\section{Discussion and conclusions}

In this study, we found that firms operating in civil law countries were more likely to have CSR statements, and that this is likely to be associated with greater employer-employee interdependence. This therefore goes some way to explain the finding in Cai et al. (2016) that country tends to matter more than firm characteristics in explaining corporate social performance, other than in the case of MNEs. Our study confirms the relevance of not just external but also internal linking of CSR behavior to the institutional tradition, and the weaker incentives for socially responsible behavior in common law countries. This conclusion is upheld when we focus on the most developed countries.

Formally committing the firm to a CSR agenda diminishes the room for maneuver by managers and owners, and their relative ability to focus on maximizing short-term returns (Carroll, 2000). This means that investment horizons may determine the nature

\footnotetext{
${ }^{5}$ A comparison of descriptive statistics between listed and non-listed firms confirms that listed firms are on average significantly larger (2627.1 employees versus 1665.9 employees) and their fourth quartile is also significantly larger $(560,004.4$ versus $165,992.9)$.
} 
of commitment to CSR, and this appeared to have knock-on effects on socially responsible HRM practice. While, clearly, legitimacy concerns and associated culturally rooted expectations are an important issue in determining CSR, the compensatory argument that firms are more likely to seek to be seen to be socially responsible in settings where ethical lapses are more likely - has limits. Any explicit CSR behavior in such instances is likely to be episodic and/or within informally set parameters rather than formalized written commitments to CSR that may be difficult to withdraw.

Our study found that firms from civil law countries were more likely to have a CSR statement. This is somewhat contrary to existing literature, which suggests that the converse is true, since in civil law countries, reputational crises are less likely, and hence the need for such statements less pressing (Matten and Moon, 2008). However, and seemingly contradictorily, we also found that firms with higher scores on the investor rights index were more likely to have a CSR statement. This would challenge the view of La Porta et al. (2008), who view investor rights and legal origin as, in the broadest sense, interchangeable. However, this could well reflect the choice of La Porta et al. (2008) to depict German, and above all, Scandinavian legal origin, as diluted forms of civil law, and hence associated with better investor protection, in order to account for their strong economic performance (particularly in the case of the latter). Nonetheless, features of each might suggest that they in fact allow for greater stakeholder influence: For example, in Scandinavia there are strong unions, and in Germany there is a strong system of workplace codetermination and worker directors (Goergen et al., 2009). If shareholder versus stakeholder rights represents a zero-sum game, as suggested by La Porta and colleagues (Botero et al., 2004), then these are countries where owner rights would be relatively weak, yet their own taxonomy suggests otherwise. There are two possible, and not necessarily incompatible, explanations. The first is that stakeholder and shareholder rights are not a zero-sum game. Strong stakeholders may drive firms to better labor standards or to be more socially responsible without necessarily leaving shareholders worse off. The second is that the broad taxonomy derived by La Porta et al. (2008), centering on legal origins, does not provide an accurate description of many economies. It can be argued that corporate law - and indeed, other formal and informal regulatory dimensions - represents the product of a complex mix of interwoven elements. Hence, there is merit to national corporate governance regime taxonomies that are derived from a much broader range of institutional features (c.f. Amable, 2013). However, a limitation of the latter is that they primarily focus on the mature economies (Amable, 2013; Jackson and Deeg, 2006). The project of extending this analysis to the developing world remains incomplete (Hancke et al., 2007). Hence, although the La Porta et al. (2008) taxonomy - which can be readily extended to encompass almost all of the world - was deployed for this study, it is recognized that the development of more complex globally relevant taxonomies for comparative institutional analysis would provide the framework for a much finer grained understanding of variations in firm practice on national lines.

Dominant national corporate governance regimes do not impose uniformity in practice (Walker et al., 2014). A great deal depends on the firm itself, including its ownership characteristics. We found that listed firms were more likely to have a CSR statement, suggesting that, rather than seeing an emphasis on CSR as an unnecessary diversion of attention away from the maximization of shareholder value, many investors are mindful of the importance of reputation for customer relations, and indeed, that an association with a firm with a poor reputation might undermine their own.

Whether a firm was multi-national or not had a significant effect on the likelihood of having a CSR statement, and engaging in socially responsible HRM practices. It has been argued that many MNEs drive down standards in their countries of domicile, and indeed, aggressively promote shareholder value in countries with greater stakeholder rights (Gooderham et al., 2008). However, we found that MNE effects did not vary across legal systems, which might suggest that MNEs do not have a particular concern with evangelizing one model over another (Brookes et al., 2017). CSR may be used as a strategic lever to grow internationally (Tixier, 2003), as it may lead to more positive views towards the firm among customers and regulators (Buckley and Ghauri, 2004; Mishra and Suar, 2010). Again, MNEs may be less likely to adopt hardline practices (especially with regard to work and employment) than their domestic counterparts, to overcome the liability of foreignness (Campbell et al., 2012), or because they have chosen to enter a particular market in order to reap the benefits of a particular production regime and will seek to enhance rather than discard practices (Whitley, 1999).

We found that MNEs were not only more likely to invest in their people, but also somewhat less likely to shed jobs. It might be the case that MNEs are better able to realize bureaucratic economies of scale across countries of domicile, while retaining a commitment to human resource development, and this is why a stronger emphasis was placed on training. In focusing on external CSR, and more specifically, community engagement, Campbell et al. (2012) found that MNEs were less, rather than more responsible. They suggest that, in part, this may be due to weaker ties with communities, and knowledge and capabilities in engaging in a manner that suits local community needs. It is likely that multi-national firms may have a greater awareness of the needs of their own employees, and hence, this may explain why we found that not only were MNEs more likely to have a CSR statement, but were also able to match this through investing in their employees. In other words, it may be easier for MNEs to be internally rather than externally socially responsible. This paper adds to the growing body of literature that applies comparative institutional analysis to firm-level policies and practices (Brookes et al., 2017; Ioannou and Serafeim, 2012), seeking to move beyond the finance literature's traditional focus on formal rules and macro-economic outcomes. It demonstrates that the relationship between setting and practice is a complex one, and that outcomes reflect both regulation and organization-specific characteristics.

In summary, our study suggests that national corporate governance regimes are very much more complex and multi-dimensional than theoretical approaches that focus on a single institutional feature might suggest. National systems embody complex mixes of owner and stakeholder rights, and these are not necessarily incompatible. The comparative corporate governance literature has tended to neglect the case of MNEs. However, we found that multinationality had a significant effect. However, rather than driving new practices associated with a stronger focus on shareholder value, we found that MNEs were more likely to adopt 
responsible practices towards their employees. This may be the case not only to compensate for the liability of foreigness, but also to gain maximum benefits from context specific human capabilities.

\section{Acknowledgements}

We would like to thank the entire Cranet team for the gathering of this data. We are also grateful to Dr. Greg Bell for his advice as well as two anonymous reviewers for their constructive criticism of an earlier version of this paper. Our gratitude also extends to the participants at the Paper Development Conference on August 2-3, 2017 at the University of Georgia Terry College of Business, and the Sustainability and Competitiveness in Business - The 15th International Annual Conference on April 18-20, 2016 at Al-Zaytoonah University, for their comments and suggestions.

\section{Appendix A. Variables definition}

\begin{tabular}{l} 
Variable \\
\hline CSR dummy \\
Employment Change \\
\\
Adjusted Employment Change \\
Training Index
\end{tabular}

Definition

Equal to one if the firm has a CSR code, and zero otherwise. From the 2009 Cranet survey.

A score indicating the increase/decrease of employees in the firm. Employment Change is equal to zero if the company had an increase in its number of employees during the last three years, 1 if the number of employees remained stable during the last three years, 2 if the company had a recruitment freeze, 3 if the company had a redeployment practice, 4 if the company had a voluntary redundancy, 5 if the company had an early retirement, 6 if the company had a no renewal of fixed-term/temporary contract, 7 if the company used outsourcing or outplacement, 8 if the company had compulsory redundancies. If a firm uses more than one practice, we focus on the most stringent practice to determine firm's score. Based on data from the 2009 Cranet survey.

Training Index

Employment Change divided by Firm Size.

A score indicating the level of training provided by the firm. It ranges from zero to five, and it is equal to the sum of the four dummy variables High Number of Days per Year Training (as per category of employee (Management, Professional, Clerical, and Manual)), plus High Percentage Annual Payroll Costs Spent on Training dummy. High Number of Days per Year Training is a dummy variable, which is set to one if the firm offers a number of training days (adjusted by staff turnover) which exceeds the sample median, High Percentage Annual Payroll Costs Spent on Training dummy is the equivalent dummy variable for an above median spent on training. Based on data from the 2009 Cranet survey.

Civil Law

Common Law

Listed dummy

MNE dummy

Firm size

Profitability

Innovation

Family dummy

M\&A dummy

Investor Rights

GNI Per Capita 2008

GNI Growth Rate

Absence of Corruption

Lack of Civil Liberties \&

Political Rights

Harmony

Egalitarianism

Intellectual Autonomy

Affective Autonomy

Power Distance

Individualism

Political

Labor Market

Macroeconomic

Infrastructure
A dummy variable, equal to one if the firm is headquartered in a civil law country, and zero otherwise.

A dummy variable, equal to one if the firm is headquartered in a common law country, and zero otherwise

A dummy variable, equal to one if the firm is listed, and zero otherwise.

A dummy variable, equal to one if the firm has a presence in more than one country, and zero otherwise. From the 2009 Cranet survey.

The total number of employees. From the 2009 Cranet survey.

Measured on a Likert scale ranging from 1 (poor or at the low end of the industry) to 5 (superior). From the 2009 Cranet survey.

Measured on a Likert scale ranging from 1 (poor or at the low end of the industry) to 5 (superior). From the 2009 Cranet survey.

A dummy variable, set to one for family firms, and zero otherwise. From the 2009 Cranet survey.

A dummy variable, equal to one for firms that have been involved in mergers and acquisitions over the past three years. From the 2009 Cranet survey.

The Djankov et al. (2008) anti-self-dealing index; it measures the level of protection enjoyed by minority shareholders.

2008 gross national income per capita in US dollars from World-Bank database.

The growth rate of gross national income per capita over 2007-2008 from the World Bank database.

Corruption Perception Index from Transparency International 2008. See also Cai et al. (2016).

Freedom House's annual survey of civil liberties and political rights, from Freedom in the World 2008 report. See also Cai et al. (2016).

Harmony from Schwartz (1999). Measures to what extent individuals prefer to fit in the natural and social world rather than bend and control it. Opposite of mastery. See also Cai et al. (2016).

Egalitarianism from Schwartz (1999). Measures the emphasis on cooperative rather than hierarchical relations in a country. See also Cai et al. (2016).

Intellectual autonomy from Schwartz (1999). Measures the emphasis on individuals pursuing their own ideas and intellectual direction in a country. See also Cai et al. (2016).

Affective autonomy from Schwartz (1999). Measures the emphasis that individuals put on pursuing a positive life experience. See also Cai et al. (2016).

Power distance index from Hofstede (1980). Measures the degree to which the less powerful members of a society accept and expect that power is distributed unequally. See also Cai et al. (2016).

Individualism index from Hofstede (1980). Measures the preference for a society in which individuals are expected to look only after themselves and their immediate families. This is the opposite of collectivism.

Competition and regulation from Ioannou and Serafeim (2012). Measures whether the laws encourage competition in the country; from the IMD World Competitiveness Report 2008

The availability of skilled labor from Ioannou and Serafeim (2012); from the IMD World Competitiveness Report 2008 Macro-economic performance measured by balance of trade (exports - imports)/GDP (see Ioannou and Serafeim, 2012); from the IMD World Competitiveness Report 2008.

Basic infrastructure from from Ioannou and Serafeim (2012). The quality of basic infrastructure in a country; from the IMD World Competitiveness Report 2008. 


\section{References}

Agle, B.R., Donaldson, T., Freeman, R.E., Jensen, M.C., Mitchell, R.K., Wood, D.J., 2008. Dialogue: toward superior stakeholder theory. Bus. Ethics Q. 18 (2), 153-190. Amable, B., 2013. Corporations in Evolving Diversity. Oxford University Press, Oxford.

Attig, N., Boubakri, N., El Ghoul, S., Guedhami, O., 2016. Firm internationalization and corporate social responsibility. J. Bus. Ethics $134,171-197$.

Avi-Yonah, R.S., 2005. The cyclical transformations of the corporate form: a historical perspective on corporate social responsibility. Law and Economics Working Papers Archive: 2003-2009, Paper 38

Bausch, A., Krist, M., 2007. The effect of context-related moderators on the internationalization-performance relationship: evidence from meta-analysis. Manag. Int. Rev. 47 (3), 319-347.

Becchetti, L., Ciciretti, R., Conzo, P., 2013. The legal origins of corporate social responsibility. CEIS working paper no. 291. Available at SSRN. http://ssrn.com/abstract= 2336179.

Becchetti, L., Ciciretti, R., Hasan, I., 2015. Corporate social responsibility, stakeholder risk, and idiosyncratic volatility. J. Corp. Finan. 35, $297-309$.

Becker-Olsen, K.L., Cudmore, A.B., Hill, P.R., 2006. The impact of perceived corporate social responsibility on consumer behavior. J. Bus. Res. 59 (1), $46-53$.

Beer, M., Boselie, P., Brewster, C., 2015. Back to the future: implications for the field of HRM of the multi-stakeholder perspective proposed 30 years ago. Hum. Resour. Manag. 54 (3), 427-438.

Bermiss, Y.S., Zajac, E.J., King, B.G., 2013. Under construction: how commensuration and management fashion affect corporate reputation rankings. Organ. Sci. 25 (2), $591-608$.

Boiral, O., 2003. The certification of corporate conduct: issues and prospects. Int. Labour Rev. 142 (3), $317-341$.

Bondy, K., Starkey, K., 2014. The dilemmas of internationalization: corporate social responsibility in the multinational corporation. Br. J. Manag. 25 (1), 4-22.

Borghesi, R., Houston, J.F., Naranjo, A., 2014. Corporate socially responsible investments: CEO altruism, reputation, and shareholder interests. J. Corp. Finan. 26 , $164-181$.

Botero, J., Djankov, S., La Porta, R., Lopez-de-Silanes, F., 2004. The regulation of labor. Q. J. Econ. 119 (4), 1339-1382.

Brewster, C., Mayrhofer, W., Morley, M. (Eds.), 2004. Human Resource Management in Europe. Evidence of Convergence?Elsevier Butterworth-Heinemann, Oxford

Brewster, C., Wood, G., Brookes, M., 2008. Similarity, isomorphism or duality? Recent survey evidence on the HRM policies of MNCs. Br. J. Manag. 19 (4), 320-342.

Brookes, M., Brewster, C., Wood, G., 2017. Are MNCs norm entrepreneurs or followers? The changing relationship between host country institutions and MNC HRM practices. Int. J. Hum. Resour. Manag. 28 (12), 1690-1711.

Bučiūnienė, I., Kazlauskaitė, R., 2012. The linkage between HRM, CSR and performance outcomes. Balt. J. Manag. 7 (1), 5-24

Buckley, P.J., Ghauri, P.N., 2004. Globalisation, economic geography and the strategy of multinational enterprises. J. Int. Bus. Stud. 35 (2), 81-98.

Cai, Y., Pan, C.H., Statman, M., 2016. Why do countries matter so much in corporate social performance? J. Corp. Finan. 41, 591-609.

Campbell, J.T., Eden, L., Miller, S.R., 2012. Multinationals and corporate social responsibility in host countries: does distance matter? J. Int. Bus. Stud. 43, 84-106.

Carroll, A.B., 2000. Ethical challenges for business in the new millennium: corporate social responsibility and models for management morality. Bus. Ethics Q. 10 (1), 33-42.

Carter, C.R., Kale, R., Grimm, C.M., 2000. Environmental purchasing and firm performance: an empirical investigation. Transp. Res. E 36 (3), $219-228$.

Cheah, E.-T., Jamali, D., Johnson, J.E.V., Sung, M.-C., 2011. Drivers of corporate social responsibility attitudes: the demography of socially responsible investors. Br. J. Manag. 22 (2), 305-323.

Cheng, B., Ioannou, I., Serafeim, G., 2014. Corporate social responsibility and access to finance. Strateg. Manag. J. 35 (1), 1-23.

Cooney, S., Gahan, P., Mitchell, R., 2011. Legal origins, labor law and the regulation of employment relations. In: Barry, M., Wilkinson, A. (Eds.), Research Handbook of Comparative Employment Relations. Edward Elgar, Cheltenham, pp. 75-97.

Cottrill, M.T., 1990. Corporate social responsibility and the marketplace. J. Bus. Ethics 9 (9), 723-729.

Crane, A., Matten, D., 2007. Business Ethics: Managing Corporate Citizenship and Sustainability in the Age of Globalization. Oxford University Press, New York.

Crane, A., Matten, D., 2016. Business Ethics. Oxford University Press, Oxford.

Crane, A., Matten, D., Spence, L.J., 2008. Corporate social responsibility. Readings and Cases in a Global Context. Routledge, Abingdon.

Deakin, S., Hobbs, R., 2007. False dawn for CSR? Shifts in regulatory policy and the response of the corporate and financial sectors in Britain. Corp. Gov. 15 (1), $68-76$.

Deegan, C., Rankin, M., Tobin, J., 2002. An examination of the corporate social and environmental disclosures of BHP from 1983-1997. A test of legitimacy theory. Account. Audit. Account. J. 15 (3), 312-343.

Djankov, S., La Porta, R., Lopez-de-Silanes, F., Shleifer, A., Vishny, R.W., 2008. The law and economics of self-dealing. J. Financ. Econ. 88 (3), $430-465$.

Dore, R., 2000. Stock Market Capitalism: Welfare Capitalism. Cambridge University Press, Cambridge.

Du, J., 2010. Institutional quality and economic crises: legal origin theory versus colonial strategy theory. Rev. Econ. Stat. 92 (1), $173-179$.

Dyer Jr., W.G., Whetten, D.A., 2006. Family firms and social responsibility: preliminary evidence from the S\&P 500. Enterp. Theory Pract. 30 (6), 785-802.

Fogarty, T., 1995. Accountant ethics: a brief examination of neglected sociological dimensions. J. Bus. Ethics 14 (2), $103-115$.

Friedman, M., 1970. The social responsibility of business is to increase its profits. New York Times Magazine, pp. 173-178 (September 13).

Gjølberg, M., 2009. The origin of corporate social responsibility: global forces or national legacies? Soc. Econ. Rev. 7 (4), $605-637$.

Goergen, M., Renneboog, L., 2010. The social responsibility of major shareholders. In: Aras, G., Crowther, D. (Eds.), The Gower Handbook of Corporate Governance and Social Responsibility. Gower, Farnham, pp. 287-305.

Goergen, M., Brewster, C., Wood, G., 2009. Corporate governance regimes and employment relations in Europe. Ind. Relat. 64 (6), $620-640$.

Goergen, M., Brewster, C., Wood, G., Wilkinson, A., 2012. Varieties of capitalism and investments in human capital. Ind. Relat. 51 (s1), $501-527$.

Goergen, M., Brewster, C., Wood, G., 2013. The effects of the national setting on employment practice: the case of downsizing. Int. Bus. Rev. 22 (6), $1051-1067$.

Gooderham, P., Fenton-O'Creevy, M., Nordhaug, O., 2008. Human resource management in US subsidiaries in Europe: centralization or autonomy? J. Int. Bus. Stud. 39 (1), 151-166.

Gray, R.H., Kouhy, R., Lavers, S., 1995. Corporate social and environmental reporting. A review of the literature and a longitudinal study of UK disclosure. Account. Audit. Account. J. 8 (2), 47-77.

Guthrie, J., Parker, L.D., 1989. Corporate social reporting: a rebuttal of legitimacy theory. Account. Bus. Res. 19 (76), $343-352$.

Hall, P., Soskice, D., 2001. An introduction to the varieties of capitalism. In: Hall, P., Soskice, D. (Eds.), Varieties of Capitalism: The Institutional Basis of Competitive Advantage. Oxford University Press, Oxford, pp. 1-68.

Hancke, B., Rhodes, M., Thatcher, M., 2007. Introduction. In: Hancke, B., Rhodes, M., Thatcher, M. (Eds.), Beyond Varieties of Capitalism: Conflict, Contradiction, and Complementarities in the European Economy. Oxford University Press, Oxford, pp. 3-38.

Harrison, J., Wicks, A., 2013. Stakeholder theory, value and firm performance. Bus. Ethics Q. 23 (1), 97-124.

Hawley, J., Williams, A., 2000. The Rise of Fiduciary Capitalism: How Institutional Investors Can Make Corporate America More Democratic. University of Pennsylvania Press, Philadelphia.

Hillman, A.J., Keim, G.D., 2001. Shareholder value, stakeholder management, and social issues: what's the bottom line? Strateg. Manag. J. 22 (2), 125-139.

Hofstede, G., 1980. Culture's Consequences: International Differences in Work-related Values. Sage Publications, Beverly Hills.

Ioannou, I., Serafeim, G., 2012. What drives corporate social performance? The role of nation-level institutions. J. Int. Bus. Stud. 43, 834-864.

Ioannou, I., Serafeim, G., 2014. The impact of corporate social responsibility on investment recommendations: analysts' perceptions and shifting institutional logics. Strateg. Manag. J. 35 (1), 1-23.

Jackson, G., Deeg, R., 2006. How many varieties of capitalism? Comparing the Comparative Institutional Analyses of Capitalist Diversity. MPIfG (Vol. Discussion Paper $06 / 2)$

Jensen, M.C., 1986. Agency costs of free cash flow, corporate finance and takeover. Am. Econ. Rev. 76, 323-329.

Kaplan, R., 2015. Who has been regulating whom, business or society? The mid-20th-century institutionalization of 'corporate responsibility' in the USA. Soc. Econ. Rev. 13 (1), 135-155. 
Kinderman, D., 2012. 'Free us up so we can be responsible!' The co-evolution of corporate social responsibility and neo-liberalism in the UK, 1977-2010. Soc. Econ. Rev. $10(1), 29-57$.

La Porta, R., Lopez-de-Silanes, F., Shleifer, A., 2008. The economic consequences of legal origins. J. Econ. Lit. 46 (2), 285-332.

Laverty, K., 1996. Economic short-termism: the debate, the unresolved issues and the implications for management research and practice. Acad. Manag. Rev. 21 (3), 825-860.

León, C.J., Araña, J.E., de León, J., 2013. Correcting for scale perception bias in measuring corruption: an application to Chile and Spain. Soc. Indic. Res. 114 (3), 977-995. Liang, H., Renneboog, L., 2017. On the foundations of corporate social responsibility. J. Financ. 72 (2), 853-910.

Marano, V., Kostova, T., 2016. Unpacking the institutional complexity in adoption of CSR practices in multinational enterprises. J. Manag. Stud. 53 (1), 28-54.

Matten, D., Moon, J., 2008. Implicit' and 'explicit' CSR: a conceptual framework for a comparative understanding of corporate social responsibility. Acad. Manag. Rev. 33 (2), 404-424.

McWilliams, A., Siegel, D.S. 2000. Corporate social responsibility and firm financial performance. Strateg. Manag. J. 21 (5), 602-609.

Mellahi, K., Harris, L., 2016. Response rates in business and management research. Br. J. Manag. 27 (2), 426-437.

Mellahi, K., Morrell, K., Wood, G.T., 2010. The Ethical Business. Palgrave, London.

Minor, D., Morgan, J., 2011. CSR as reputation insurance: Primum non nocere. Calif. Manag. Rev. 53 (3), 40-59.

Mishra, S., Suar, D., 2010. Does corporate social responsibility influence firm performance of Indian companies? J. Bus. Ethics 95 (4), 571-601.

Mitchell, T.R., 1985. An evaluation of the validity of correlational research conducted in organizations. Acad. Manag. Rev. 10 (2), 192-205.

Morgan, G., 2012. International business, MNCs and national systems. In: Demirbag, M., Wood, G. (Eds.), Handbook of Institutions and International Business. Elgar, Cheltenham.

Pagano, M., Panetta, F., Zingales, L., 1998. Why do companies go public? An empirical analysis. J. Financ. 53 (1), 27-64.

Palazzo, G., Scherer, A., 2006. Corporate legitimacy as deliberation: a communicative framework. J. Bus. Ethics 66 (1), 71-88.

Park, J., Lee, H., Kim, C., 2014. Corporate social responsibilities, consumer trust and corporate reputation: South Korean consumers' perspectives. J. Bus. Res. 67 (3), 295-302.

Parry, E., Stavrou, E., Lazarova, M. (Eds.), 2013. Global Trends in Human Resource Management. Palgrave Macmillan, Basingstoke.

Patten, D.M., 1991. Exposure legitimacy, and social disclosure. J. Account. Public Policy 10 (4), 297-308.

Podsakoff, P.M., Organ, D.W., 1986. Self-reports in organizational research: problems and prospects. J. Manag. 12 (4), 531-544.

Sacconi, L., 1999. Codes of ethics and contractarian constraints on the abuse of authority within hierarchies: a perspective from the theory of the firm. J. Bus. Ethics 21 (2\&3), 189-202.

Schwartz, S.H., 1999. A theory of cultural values and some implications for work. Appl. Psychol. Int. Rev. 48 (1), 23-47.

Sen, S., Cowley, J., 2013. The relevance of stakeholder theory and social capital theory in the context of CSR in SMEs: an Australian perspective. J. Bus. Ethics 118 (2), 413-427.

Shea, L.J., 2010. Using consumer perceived ethicality as a guideline for corporate social responsibility strategy: a commentary essay. J. Bus. Res. 63 (3), $263-264$.

Tixier, M., 2003. Soft vs. hard approach in communicating on corporate social responsibility. Thunderbird Int. Bus. Rev. 45 (1), 71-91.

Transparency International, 2010. https://www.transparency.org/research/cpi/cpi_2008/0 accessed on 21 August 2017.

Van Cranenburgh, K., Liket, K., Roome, N., 2013. Management responses to social activism in an era of corporate responsibility. J. Bus. Ethics 118 (3), $497-513$.

Waddock, S., Graves, S., 1997. The corporate social performance-financial performance link. Strateg. Manag. J. 18 (4), 303-319.

Walker, J.T., Brewster, C., Wood, G., 2014. Diversity between and within varieties of capitalism: transnational survey evidence. Ind. Corp. Chang. 23 (2), 493-533.

Weaver, G.R., Trevino, L.K., Cochran, P.L., 1999. Corporate ethics programs as control systems: influences of executive commitment and environmental factors. Acad. Manag. J. 42 (1), 41-57.

Whitley, R., 1999. Divergent Capitalisms. Oxford University Press, Oxford.

Wickert, C., Scherer, A.G., Spence, L.J., 2016. Walking and talking corporate social responsibility: implications of firm size and organizational cost. J. Manag. Stud. 53, 1169-1196.

Wood, G.T., Dibben, P., Ogden, S., 2014. Comparative capitalism without capitalism, and production without workers: the limits and possibilities of contemporary institutional analysis. Int. J. Manag. Rev. 16, 384-396.

Woodward, D.G., Edwards, P., Birkin, F., 1996. Organizational legitimacy and stakeholder information provision. Br. J. Manag. 7 (4), 329-347.

World Bank, 2017. https://data.worldbank.org/indicator/NY.GNP.PCAP.CD accessed on 21 August 2017.

Zander, L., Jonson, K., Mockaitis, A., 2016. Leveraging values in global organizations: premises, paradoxes and progress. Manag. Int. Rev. 56 (2), 149-169. 